Article

\title{
Carbonaceous Aerosols in Contrasting Atmospheric Environments in Greek Cities: Evaluation of the EC-tracer Methods for Secondary Organic Carbon Estimation
}

\author{
Dimitris G. Kaskaoutis ${ }^{1}$, Georgios Grivas ${ }^{1}$, Christina Theodosi ${ }^{1}$, Maria Tsagkaraki ${ }^{2}$, \\ Despina Paraskevopoulou $^{1}$ (D), Iasonas Stavroulas ${ }^{1}$, Eleni Liakakou ${ }^{1}$, Antonis Gkikas ${ }^{3} \mathbb{D}^{1}$, \\ Nikolaos Hatzianastassiou ${ }^{4}$, Cheng $\mathrm{Wu}^{5,6}{ }^{\mathbb{D}}$, Evangelos Gerasopoulos ${ }^{1}$ and \\ Nikolaos Mihalopoulos $1,2, *$ (D)
}

1 Institute for Environmental Research and Sustainable Development, National Observatory of Athens, 15236 Athens, Greece; dkask@noa.gr (D.G.K.); ggrivas@noa.gr (G.G.); c_theodosi@chemistry.uoc.gr (C.T.); dparask@noa.gr (D.P.); i.stavroulas@noa.gr (I.S.); liakakou@noa.gr (E.L.); egera@noa.gr (E.G.)

2 Environmental Chemical Processes Laboratory, Department of Chemistry, University of Crete, 70013 Crete, Greece; tsagaraki-maria@hotmail.com

3 Institute for Astronomy, Astrophysics, Space Applications and Remote Sensing, National Observatory of Athens, 15784 Athens, Greece; agkikas@noa.gr

4 Laboratory of Meteorology, Department of Physics, University of Ioannina, 45110 Ioannina, Greece; nhatzian@uoi.gr

5 Institute of Mass Spectrometer and Atmospheric Environment, Jinan University, Guangzhou 510632, China; wucheng.vip@foxmail.com

6 Guangdong Provincial Engineering Research Center for On-line Source Apportionment System of Air Pollution, Guangzhou 510632, China

* Correspondence: nmihalo@noa.gr; Tel.: +30-2108109121

Received: 12 December 2019; Accepted: 29 January 2020; Published: 4 February 2020

\begin{abstract}
This study examines the carbonaceous-aerosol characteristics at three contrasting urban environments in Greece (Ioannina, Athens, and Heraklion), on the basis of $12 \mathrm{~h}$ sampling during winter (January to February 2013), aiming to explore the inter-site differences in atmospheric composition and carbonaceous-aerosol characteristics and sources. The winter-average organic carbon (OC) and elemental carbon (EC) concentrations in Ioannina were found to be 28.50 and $4.33 \mu \mathrm{g} \mathrm{m}^{-3}$, respectively, much higher than those in Heraklion $\left(3.86 \mu \mathrm{g} \mathrm{m}^{-3}\right.$ for OC and $2.29 \mu \mathrm{g} \mathrm{m}^{-3}$ for EC) and Athens (7.63 $\mathrm{g} \mathrm{m} \mathrm{m}^{-3}$ for OC and $2.44 \mu \mathrm{g} \mathrm{m}^{-3}$ for EC). The winter OC/EC ratio in Ioannina (6.53) was found to be almost three times that in Heraklion (2.03), indicating a larger impact of wood combustion, especially during the night, whereas in Heraklion, emissions from biomass burning were found to be less intense. Estimations of primary and secondary organic carbon (POC and SOC) using the EC-tracer method, and specifically its minimum $R$-squared (MRS) variant, revealed large differences between the sites, with a prevalence of POC (67-80\%) in Ioannina and Athens and with a larger SOC fraction (53\%) in Heraklion. SOC estimates were also obtained using the $5 \%$ and $25 \%$ percentiles of the OC/EC data to determine the $(\mathrm{OC} / \mathrm{EC})_{\text {pri }}$, leading to results contrasting to the MRS approach in Ioannina (70-74\% for SOC). Although the MRS method provides generally more robust results, it may significantly underestimate SOC levels in environments highly burdened by biomass burning, as the fast-oxidized semi-volatile OC associated with combustion sources is classified in POC. Further analysis in Athens revealed that the difference in SOC estimates between the $5 \%$ percentile and MRS methods coincided with the semi-volatile oxygenated organic aerosol as quantified by aerosol mass spectrometry. Finally, the $\mathrm{OC} / \mathrm{K}_{\mathrm{bb}}{ }^{+}$ratio was used as tracer for decomposition of the POC into fossil-fuel and biomass-burning components, indicating the prevalence of biomass-burning POC, especially in Ioannina (77\%).
\end{abstract}


Keywords: carbonaceous aerosols; inorganic species; POC-SOC estimation; biomass burning; MRS method; Greece

\section{Introduction}

Carbonaceous aerosols (organic carbon, OC; organic matter, OM; elemental or black carbon, $\mathrm{EC}$ or $\mathrm{BC}$, respectively) constitute the dominant component of aerosols in the urban environment and are mainly classified in the fine-mode fraction. They include toxic compounds and induce adverse impacts on the human respiratory and circulatory systems [1-4]. EC is emitted from the incomplete combustion of fossil fuels and any kind of biomass and, being chemically inert, it can be sustained in the atmosphere for several days, contributing to a large degree in atmospheric warming [5-7]. Conversely, OC can be produced by both primary (primary organic carbon; POC) combustion and non-combustion sources, as well as secondary processes (secondary organic carbon; SOC) involving the gas-phase oxidation of precursor biogenic and anthropogenic volatile organic compounds (VOCs), as well as aqueous-cloud heterogeneous reactions [8-11]. Although OC is a mostly scattering aerosol type, a part of it-termed brown carbon-can strongly absorb in the ultraviolet and shorter visible wavelengths, with considerable effects on atmospheric radiative heating [12-14].

Biomass burning (BB) is a major source of carbonaceous aerosols in the atmosphere $[1,15,16]$ and contributes to the production of secondary organic aerosol (SOA) $[17,18]$. Since the winter of 2012-2013, the atmospheric composition in Athens and other major Greek cities has been substantially modified due to enhanced emissions from residential wood burning (RWB), as a consequence of the economic recession and the increase in the price of heating oil [19-24]. The result was a remarkable escalation in winter night-time concentrations of particulate matter (PM), carbonaceous aerosols, and biomass-burning tracers, documented mainly in Athens [25,26], but also in other Greek cities such as Thessaloniki [19] and Patras [27].

Several studies have been conducted in Greece during the last decade, dealing with carbonaceous-aerosol characteristics and source apportionment [28-35]. However, there is a knowledge-gap regarding the POC and SOC fractions and their spatio-temporal characteristics in this changing urban landscape. Estimations of SOC and POC in Athens have previously been performed at a central site, during January to August 2003 [36] and at a regional background site for the warm periods during 2008-2013 [20], mostly prior to the onset of the air-quality issue related to RWB. Furthermore, POC and SOC estimates have been provided for urban traffic and background sites in Thessaloniki (northern Greece) in 2011 to 2012 [37] and in Finokalia (a remote coastal site in Crete) from 2004 to 2007 [38]. The updated assessment of SOC contributions and variability is considered essential, especially due to its role in the generation of reactive oxygen species, which are related to oxidative stress and participate in the key biologically plausible mechanism for inflammation following inhalation exposure [39].

In this study, a wintertime field campaign was carried out during January-February 2013 and data were collected simultaneously in the urban areas of Athens, Heraklion, and Ioannina, characterized by contrasting meteorological and atmospheric conditions, topography, and emission sources. Ioannina and Heraklion exhibit mean temperature differences of $\approx 10^{\circ} \mathrm{C}$ in winter, whereas Athens is geographically located between them. In terms of population, Ioannina and Heraklion are small-medium sized cities with 80,000 and 150,000 inhabitants, respectively, whereas the metropolitan area of Athens is among the 10 most populous in Europe (about 3.5 million). Various approaches anchored in the long-established EC-tracer method [40] are followed for the estimation of SOC, namely, the $5 \%$ and $25 \%$ lowest percentiles of the OC/EC ratios, respectively, and the recently-established minimum $R$-squared (MRS) method [41,42]. The MRS method was applied here for the first time in European cities, and extensive analysis was performed regarding its reliability and the challenges in its application at sites receiving intense BB emissions. The key aim of this work was the evaluation of the 
SOC and POC estimates from the EC-tracer methods, and their comparison with those derived from aerosol chemical speciation monitor (ACSM) measurements. As the equipment and operation costs of aerosol mass spectrometric methods are high, the evaluation of the EC-tracer method at contrasting environments is important, as it provides a useful alternative to scientists and decision makers for obtaining SOC estimates.

The specific objectives of this study were (i) the investigation of the differences in atmospheric chemical composition between Greek cities, with emphasis on carbonaceous aerosols; (ii) the assessment of the POC and SOC components using different techniques based on the EC-tracer method; (iii) the evaluation of the reliability and biases of the MRS method for SOC estimations in highly BB-burdened atmospheres; (iv) the comparison of the SOC and POC estimates with data of organic aerosol components derived from on-line aerosol mass spectrometric measurements; and finally, (v) an initial attempt to discern between fossil-fuel and BB contributions to the POC concentrations estimated by the EC-tracer method.

\section{Study Sites, Data, and Experimental Details}

Ioannina is a city in the northwest part of Greece, lying on a plateau at an elevation of about $500 \mathrm{~m}$ and surrounded by mountains ( $\approx 1800-2400 \mathrm{~m}$ ). The city is next to the Pamvotis lake (Figure 1), and is characterized by frequent fog during wintertime, due to increased relative humidity, weak winds and basin-like characteristics, whereas the mean winter temperature is $\approx 6-9{ }^{\circ} \mathrm{C}$ [43]. Notwithstanding the low temperatures, which lead to excessive RWB and humid conditions and, therefore, to the appearance of intense smog events, particle pollution in Ioannina has been minimally documented [44]. In this study, filter samples $(n=60)$ were collected during January to February 2013, at an urban-background location near the city center, at $12 \mathrm{~h}$ intervals (day: 06:00-18:00 Local Standard Time, (LST); night: 18:00-06:00 LST). Total suspended particulate (TSP) measurements were performed using a NILU one-stage filter holder system at a flow rate of $1.5 \mathrm{~m}^{3} / \mathrm{hr}$. In view of the high concentration levels observed, the sampling campaign was also repeated at the same site in the next winter (December to February 2013/2014; 61 samples), whereas 20 samples were also collected in the intermediate period between successive winters (Table S1). The coastal city of Heraklion is the largest city in the island of Crete, with a Mediterranean climate characterized by mild winters and hot summers (Figure 1). During winter, the area is affected by western depressions with temperatures usually ranging from $\approx 7$ ${ }^{\circ} \mathrm{C}$ to $16{ }^{\circ} \mathrm{C}$, whereas under favorable conditions it comes under the influence of intense Saharan dust events [45]. The bulk air-sample (TSP) measurements in Heraklion were also performed separately for daytime and night-time during January to February 2013, using the same sampling device as in Ioannina (Table S1). In Athens, $\mathrm{PM}_{2.5}$ sample measurements were performed at the atmospheric monitoring station in Thissio (Figure 1), an urban-background site located in the city center [24,46]. Particles were collected using a Dichotomous Partisol Sampler 2025 (Thermo Scientific Inc.), at a flow rate of $16.71 \mathrm{~min}^{-1}$, also at $12 \mathrm{~h}$ (day/night) intervals (Table S1).

The quartz-fiber filters $(47 \mathrm{~mm})$, used at all sites, were stored at controlled temperature $(20 \pm 3$ ${ }^{\circ} \mathrm{C}$ ) and relative humidity ( $\mathrm{RH}: 40 \% \pm 5 \%$ ) pre- and post-weighting, with an analytical microbalance (MX-5, Mettler-Toledo, Inc., Columbus, Ohio, USA, readability of $1 \mu \mathrm{g}$ ). All filters were analyzed for OC and EC concentrations using a Sunset Laboratory OC/EC Analyzer (Thermal-Optical Transmission, TOT) and applying the EUSAAR-2 protocol [20,47]. A compensation [48] was applied in TSP filters for carbonate carbon, which is associated with soil-originating coarse particles. The carbonate carbon fraction introduces a bias in the OC quantification, as it evolves as OC in the final step of the inert-mode temperature protocol. In the present case, carbonate carbon was quantified by manual integration of the last (fourth) peak appearing at the maximum temperature step [48] and was subtracted from the total OC mass. The interference from other coarse OC particles (e.g., bio-aerosols) is expected to be low [36]. The detection limits for $\mathrm{OC}$ and EC were 0.26 and $0.05 \mu \mathrm{g} \mathrm{C} \mathrm{cm}^{-2}$, respectively, and the final concentrations were blank corrected [24]. In addition, water-soluble species $\left(\mathrm{Cl}^{-}, \mathrm{SO}_{4}{ }^{2-}, \mathrm{NO}_{3}{ }^{-}, \mathrm{C}_{2} \mathrm{O}_{4}{ }^{2-}\right.$, $\left.\mathrm{NH}_{4}{ }^{+}, \mathrm{K}^{+}, \mathrm{Na}^{+}, \mathrm{Mg}^{2+}, \mathrm{Ca}^{2+}\right)$ at all stations were detected from filters using ion chromatography [20]. 


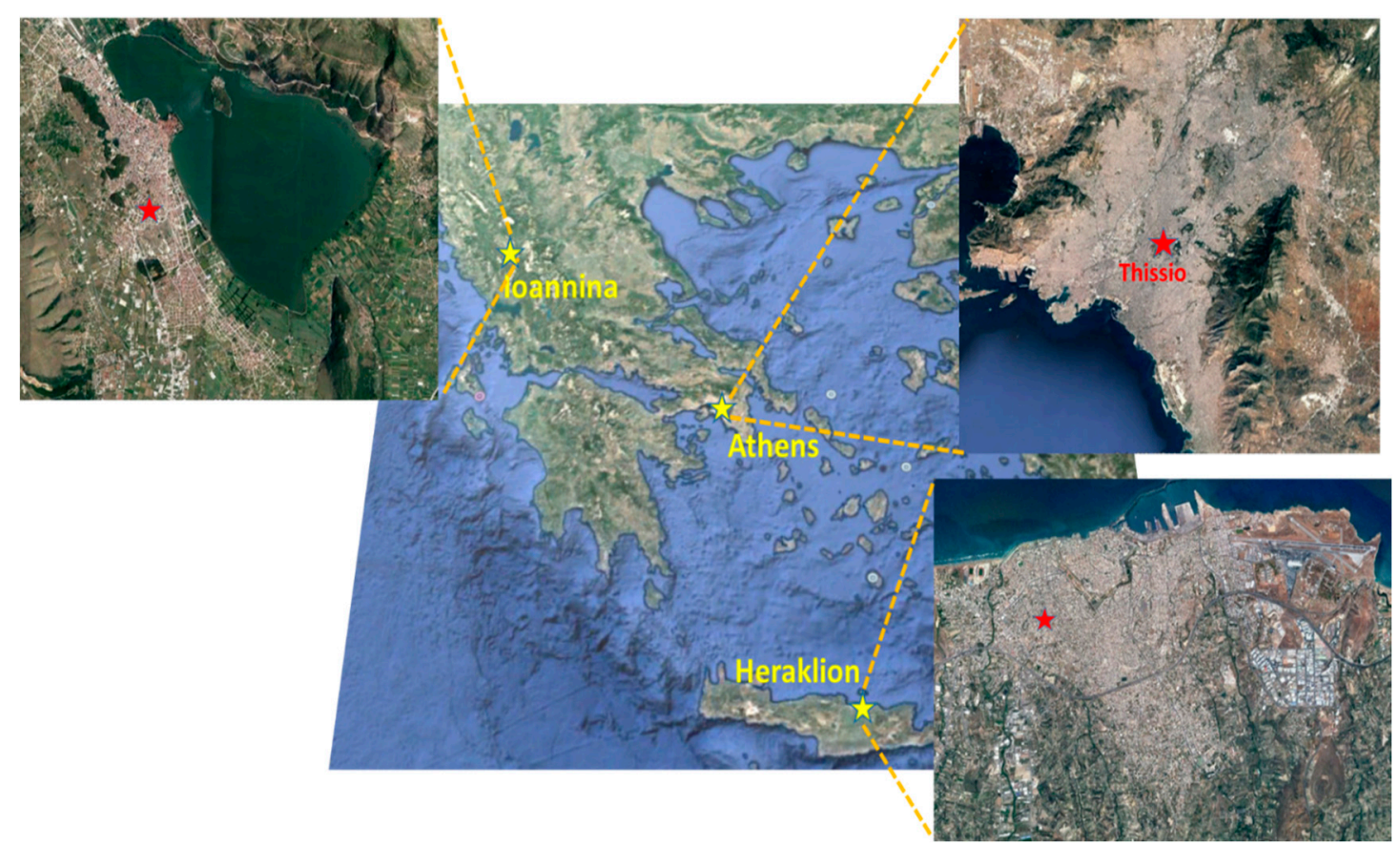

Figure 1. Map of the sampling sites (red stars) in Ioannina, Athens (Thissio), and Heraklion.

Furthermore, we utilized BC concentrations in Athens (Thissio) during the winter period of December 2016 to January 2017 measured with a seven-wavelength AE-33 Aethalometer sampling through a $\mathrm{PM}_{2.5}$ cyclone. We also calculated the decomposed $\mathrm{BC}$ components related to fossil-fuel and biomass-burning emissions $\left(\mathrm{BC}_{\mathrm{ff}}\right.$ and $\mathrm{BC}_{\mathrm{bb}}$, respectively). These hourly $\mathrm{BC}, \mathrm{BC}_{\mathrm{ff}}$, and $\mathrm{BC}_{\mathrm{bb}}$ measurements were thoroughly presented and analyzed by Liakakou et al. [34] for a 4 year period. In the current study, they were used for comparison with the SOC and POC estimates from the EC-tracer method.

Non-refractory submicron $\left(\mathrm{PM}_{1}\right)$ organic aerosol $(\mathrm{OA})$ and inorganic species (sulfate, nitrate, ammonium, chloride) were measured in Athens with a collocated ACSM [33]. From this dataset, we used the organic aerosol (OA) components calculated during December 2016 to January 2017 for comparisons with the POC and SOC fractions estimated using the EC-tracer method. Five separate OA factors were deconvolved using PMF (positive matrix factorization), namely, hydrocarbon-like organic aerosol (HOA), cooking organic aerosol (COA), biomass-burning organic aerosol (BBOA), semi-volatile oxygenated organic aerosol (SV-OOA), and low-volatility oxygenated organic aerosol (LV-OOA). Details on the ACSM setup, calibration, quality assurance, and data management, as well as a thorough discussion on the implemented PMF strategy, can be found in Stavroulas et al. [33]. The hourly AE-33 and ACSM data were averaged at $12 \mathrm{~h}$ intervals (day and night), consistent with the OC and EC measurements from $\mathrm{PM}_{2.5}$ samples $(n=118)$.

\section{Methodology}

The EC-tracer method has been extensively used for the estimation of primary and secondary aerosol contributions $[40,42,49]$, on the basis of measured OC and EC concentrations and an appropriately selected primary OC to EC ratio:

$$
\begin{gathered}
\mathrm{POC}=[\mathrm{EC}] \times(\mathrm{OC} / \mathrm{EC})_{\text {pri }} \\
\mathrm{SOC}=[\mathrm{OC}]-(\mathrm{OC} / \mathrm{EC})_{\text {pri }} \times[\mathrm{EC}]
\end{gathered}
$$

The main concern in the method is the accurate determination of the $(\mathrm{OC} / \mathrm{EC})_{\text {pri }}$ ratio. Several studies have used the minimum or an average of the $3-5$ lowest OC/EC ratios [36,37,50,51], 
whereas others have isolated "SOC-free" data subsets using lower percentiles (e.g., 5-25\%) of OC/EC ratio values and then determined the $(\mathrm{OC} / \mathrm{EC})_{\text {pri }}$ through linear regression $[36,52,53]$. The use of $(\mathrm{OC} / \mathrm{EC})_{\min }$ results in reliable estimates in cases of small SOC contribution in the samples used for the determination of $(\mathrm{OC} / \mathrm{EC})_{\mathrm{min}}$ and if the compositions of $\mathrm{POC}$ from fossil-fuel emissions are spatially and temporally constant, with low contribution from other sources (BB and biogenic aerosols) $[49,52]$. The main uncertainty on the determination of $(\mathrm{OC} / \mathrm{EC})_{\text {pri }}$ lies in the lack of a definite criterion for the selection of a percentile that provides the most accurate representation of $(\mathrm{OC} / \mathrm{EC})_{\text {pri, }}$, which in turn may vary spatially and temporally [42]. Wu and $\mathrm{Yu}$ [41] integrated in the EC-tracer method the minimum $R$-squared (MRS) method, initially described by Millet et al. [54], as a more robust solution for obtaining reliable SOC estimates, compared to (OC/EC $)_{\min }$ and percentile methods. The MRS method is based on the assumption that EC is inherently unrelated to SOC and, therefore, the (OC/EC) pri should be the ratio resulting in minimum correlation $\left(R^{2}\right)$ between estimated SOC and measured EC in Equation (2). A detailed description and software solutions for the MRS procedure are provided by Wu et al. [42]. Results from its application in the present datasets (Ioannina, Heraklion) can be seen in Figure S1. In this study, we used both the MRS and lower percentile (5\% and $25 \%$ ) methods for the estimation of SOC (and POC), and the results were compared between the three sites. Given the intensity of primary combustion sources observed in the study, the POC fraction associated with non-combustion sources in urban areas was considered relatively low $[49,55]$ and excluded from the analysis. It is noted that Grivas et al. [36] have previously estimated small non-combustion OC concentrations of $0.2-0.4 \mu \mathrm{g} \mathrm{m}^{-3}$ in Athens.

\section{Results and Discussion}

\subsection{Carbonaceous-aerosol Characteristics}

Table 1 summarizes the OC and EC concentrations and OC/EC ratios. An average OC concentration of $25.37 \pm 27.06 \mu \mathrm{g} \mathrm{m}^{-3}\left(1.3-141.7 \mu \mathrm{g} \mathrm{m}^{-3}\right)$ was calculated for the whole measurement period $(n=$ $132)$ in Ioannina ( $28.50 \mathrm{\mu g} \mathrm{m}^{-3}$ for winter-only samples). In Heraklion, a winter average of $3.86 \pm$ $2.99 \mu \mathrm{g} \mathrm{m}^{-3}$ was observed, with a comparably limited variability between day $\left(3.56 \mu \mathrm{g} \mathrm{m}^{-3}\right)$ and night $\left(4.17 \mathrm{\mu g} \mathrm{m}^{-3}\right)$, implying weaker emissions from RWB. In Athens, the mean OC concentration was 7.61 $\pm 5.42 \mu \mathrm{g} \mathrm{m}^{-3}$, with notably higher levels during night $\left(9.60 \mu \mathrm{g} \mathrm{m}^{-3}\right)$. During the common period (January to February 2013), the average OC concentration in Ioannina was $19.50 \mu \mathrm{g} \mathrm{m}^{-3}$, whereas it was much higher during the winter of 2013/2014 $\left(39.26 \pm 36.08 \mu \mathrm{g} \mathrm{m}^{-3}\right)$ due to increased wood-burning emissions and comparably lower amounts of rainfall ( $343 \mathrm{~mm}$ during the sampling period in January to February 2013, and $147 \mathrm{~mm}$ on the sampling days in December 2013 to February 2014).

The enhanced carbonaceous-aerosol concentrations in Ioannina were found to be much higher than those measured in other Greek cities during the recent years of the economic recession, and the differences cannot be entirely ascribed to the fact that the present measurements are for TSP particles. Cold period OC levels of 4.1-7.9 $\mathrm{\mu g} \mathrm{m}^{-3}$ were determined from $\mathrm{PM}_{10}$ samples at suburban and urban/background sites in Athens and 8.7 to $14.2 \mu \mathrm{g} \mathrm{m}^{-3}$ at urban/background and urban traffic sites in Thessaloniki during 2011-2012 [22]. On the contrary, lower OC concentrations in the range of 2-7 $\mu \mathrm{g} \mathrm{m}^{-3}$ were registered in Greek cities during the years preceding the economic recession, that is, before 2010/2011 [20,28,36,56]. The OC levels in Ioannina are comparable or even higher than those $\left(\approx 10-25 \mu \mathrm{g} \mathrm{m}^{-3}\right)$ for TSP measurements in Asian heavily polluted cities such as Tianjin, China [57]; Shanghai, China [58]; Agra, India [59]; and Kolkata, India [60].

The EC mean concentration in Ioannina $\left(4.14 \pm 3.67 \mu \mathrm{g} \mathrm{m}^{-3}\right.$; range of $\left.0.14-24.42 \mu \mathrm{g} \mathrm{m}^{-3}\right)$ was found to be about double that of those in Athens $\left(2.44 \pm 3.28 \mu \mathrm{g} \mathrm{m}^{-3}\right)$ and Heraklion $\left(2.29 \pm 2.40 \mu \mathrm{g} \mathrm{m}^{-3}\right)$ (Table 1), and much higher than previously reported values in Athens, for instance, $2.8 \pm 1.2 \mu \mathrm{g} \mathrm{m}^{-3}$ during the winters of 2013-2015 [24]. Other studies have measured average winter BC concentrations in Athens in the range of 2.4-3.0 $\mathrm{gg} \mathrm{m}^{-3}[25,30,32,34]$, much lower than the EC levels in Ioannina, whereas the pre-recession EC levels in Greek cities were even lower $[20,28,36,56]$. The very high 
concentrations of OC and EC at Ioannina are attributed to enhanced RWB emissions within the urban area and in the surrounding villages. Wood burning in fireplaces and woodstoves is a common means for space heating in mountainous northern Greece, also given the availability of high-heating value wood-fuel that is prolifically cultivated in the area [61]. The pattern of elevated OC and EC levels during winter is typically observed in other cold and mountainous areas in Europe [62-65].

Table 1. Mean values of carbonaceous-aerosol parameters at the study sites. POC (primary organic carbon) and SOC (secondary organic carbon) refer to estimates by the minimum $R$-squared (MRS) method. OC: organic carbon; EC: elemental carbon.

\begin{tabular}{cccccccc}
\hline Ioannina & $\begin{array}{c}\text { OC } \\
\left(\mu \mathrm{g} \mathrm{m}^{-3}\right)\end{array}$ & $\begin{array}{c}\mathrm{EC} \\
\left(\mu \mathrm{g} \mathrm{m}^{-3}\right)\end{array}$ & OC/EC & $\begin{array}{c}\text { POC } \\
\left(\mu \mathrm{g} \mathrm{m}^{-3}\right)\end{array}$ & $\begin{array}{c}\text { SOC } \\
\left(\mu \mathrm{g} \mathrm{m}^{-3}\right)\end{array}$ & POC/OC & SOC/OC \\
\hline All & $25.37 \pm 27.06$ & $4.14 \pm 3.67$ & $5.98 \pm 2.58$ & $20.37 \pm 20.51$ & $5.00 \pm 9.41$ & $0.80 \pm 0.21$ & $0.20 \pm 0.21$ \\
\hline Winter & $28.50 \pm 28.18$ & $4.33 \pm 3.89$ & $6.53 \pm 2.33$ & $23.35 \pm 20.89$ & $5.15 \pm 10.05$ & $0.82 \pm 0.15$ & $0.18 \pm 0.15$ \\
\hline Non-winter & $7.82 \pm 4.94$ & $3.08 \pm 1.68$ & $2.89 \pm 1.56$ & $3.65 \pm 2.00$ & $4.18 \pm 4.42$ & $0.47 \pm 0.24$ & $0.53 \pm 0.24$ \\
\hline Night & $34.48 \pm 31.76$ & $4.79 \pm 4.52$ & $7.36 \pm 2.15$ & $27.18 \pm 23.34$ & $7.30 \pm 11.75$ & $0.79 \pm 0.17$ & $0.21 \pm 0.17$ \\
\hline Day & $16.66 \pm 13.49$ & $3.55 \pm 2.11$ & $4.63 \pm 1.52$ & $16.15 \pm 12.53$ & $0.51 \pm 1.38$ & $0.97 \pm 0.08$ & $0.03 \pm 0.08$ \\
\hline & & \multicolumn{7}{c}{ Heraklion } & & \\
\hline All & $3.86 \pm 2.99$ & $2.29 \pm 2.40$ & $2.03 \pm 1.05$ & $1.82 \pm 1.64$ & $2.04 \pm 2.04$ & $0.47 \pm 0.17$ & $0.53 \pm 0.17$ \\
\hline Night & $4.17 \pm 2.41$ & $2.44 \pm 2.91$ & $2.37 \pm 1.22$ & $1.84 \pm 1.79$ & $2.34 \pm 1.90$ & $0.44 \pm 0.19$ & $0.56 \pm 0.19$ \\
\hline Day & $3.56 \pm 3.48$ & $2.15 \pm 1.79$ & $1.70 \pm 0.73$ & $1.80 \pm 1.51$ & $1.76 \pm 2.17$ & $0.51 \pm 0.14$ & $0.49 \pm 0.14$ \\
\hline & & \multicolumn{7}{c}{ Athens } & & \\
\hline All & $7.63 \pm 7.33$ & $2.44 \pm 3.28$ & $6.42 \pm 6.41$ & $5.09 \pm 6.91$ & $2.54 \pm 1.86$ & $0.67 \pm 0.28$ & $0.33 \pm 0.28$ \\
\hline Night & $9.60 \pm 8.05$ & $3.13 \pm 3.89$ & $7.45 \pm 7.39$ & $6.59 \pm 7.58$ & $3.01 \pm 1.92$ & $0.69 \pm 0.29$ & $0.31 \pm 0.29$ \\
\hline Day & $5.00 \pm 3.78$ & $1.46 \pm 1.43$ & $5.20 \pm 5.12$ & $2.98 \pm 2.35$ & $2.02 \pm 1.68$ & $0.59 \pm 0.34$ & $0.41 \pm 0.34$ \\
\hline
\end{tabular}

$\mathrm{OC} / \mathrm{EC}$ as a diagnostic ratio is commonly used for qualitative assessment of carbonaceous-aerosol sources and discerning between primary emissions and SOA formation [66-69]. OC/EC values from BB emissions generally exhibit a wide range ( $\approx 4-16)$ depending on the burning material, moisture content, fire conditions (flaming or smoldering), and aging [70,71] and are higher than those from fossil-fuel combustion (with values typically up to 2). Measurements at sites with heavy diesel-vehicle traffic, road tunnels, or that are close to fossil-fuel combustion point-sources can lead to OC/EC ratios around 1.0 or even lower $[49,71,72]$. On the other hand, the photo-oxidation processes and SOA formation also inflate the OC/EC ratio [20,73]. Here, an average OC/EC ratio of $5.98 \pm 2.58$ was computed in Ioannina for all the available samples, with higher values $(6.53 \pm 2.33)$ during winter compared to non-winter $(2.89 \pm 1.56)$ samples (Table 1$)$, indicating that the high levels are directly associated with BB emissions and their processing. Furthermore, the winter night-time samples exhibited higher OC/EC ratios $(7.36$ $\pm 2.15)$ compared to daytime $(4.63 \pm 1.52)$, whereas in Heraklion, a much lower day-night difference was detected, with a winter average OC/EC of $2.03 \pm 1.05$ (Table 1). In Athens, a mean OC/EC of $6.42 \pm$ 6.79 was found with higher values during night $(7.45 \pm 7.39)$.

Previous studies have found lower OC/EC values in Greece [20,22]. Jedynska et al. [74] reported an average OC/EC ratio of 2.6 during the cold period of 2010-2011 in $\mathrm{PM}_{2.5}$ sampled across 20 sites with variable characteristics in the greater Athens area. The lower OC/EC values during the period before the economic recession have substantially increased in the following years. Indicatively, OC/EC averages of 8.9, 7.3, and 9.4 were reported for $\mathrm{PM}_{2.5}$ at suburban Athens, urban Athens, and urban Thessaloniki sites, respectively, during the cold period of 2011-2012, indicating high primary emissions from wood combustion [22]. In addition, Saffari et al. [19] reported OC/EC values of 8.7-13.3 in Thessaloniki while studying wood-burning events during the winter of 2012-2013.

The much larger impact of RWB emissions in Ioannina is supported by the observed OC vs. EC statistical associations (Figure 2). Remarkable inter-site variation is displayed for the slope values, implying differences in the relative dominance of emission sources and organic aerosol processing. 
The large $R^{2}$ values (0.72-0.92) in Ioannina and Athens largely indicate the impact of local primary sources (mainly traffic and biomass burning). A strong linear association $\left(R^{2}=0.88\right.$; slope $=2.36$ ) has been reported at the same site in Athens during the three winter periods (2013/2014, 2014/2015, 2015/2016), revealing the continuous, long-term effect of primary RWB emissions in the area [24]. In contrast, the much lower OC/EC correlation in Heraklion $\left(R^{2}=0.45\right)$ possibly suggests increased SOC formation (photochemical formation is possible even during winter in Southern Greece due to fair weather conditions) and the influence from regional background carbonaceous aerosols.

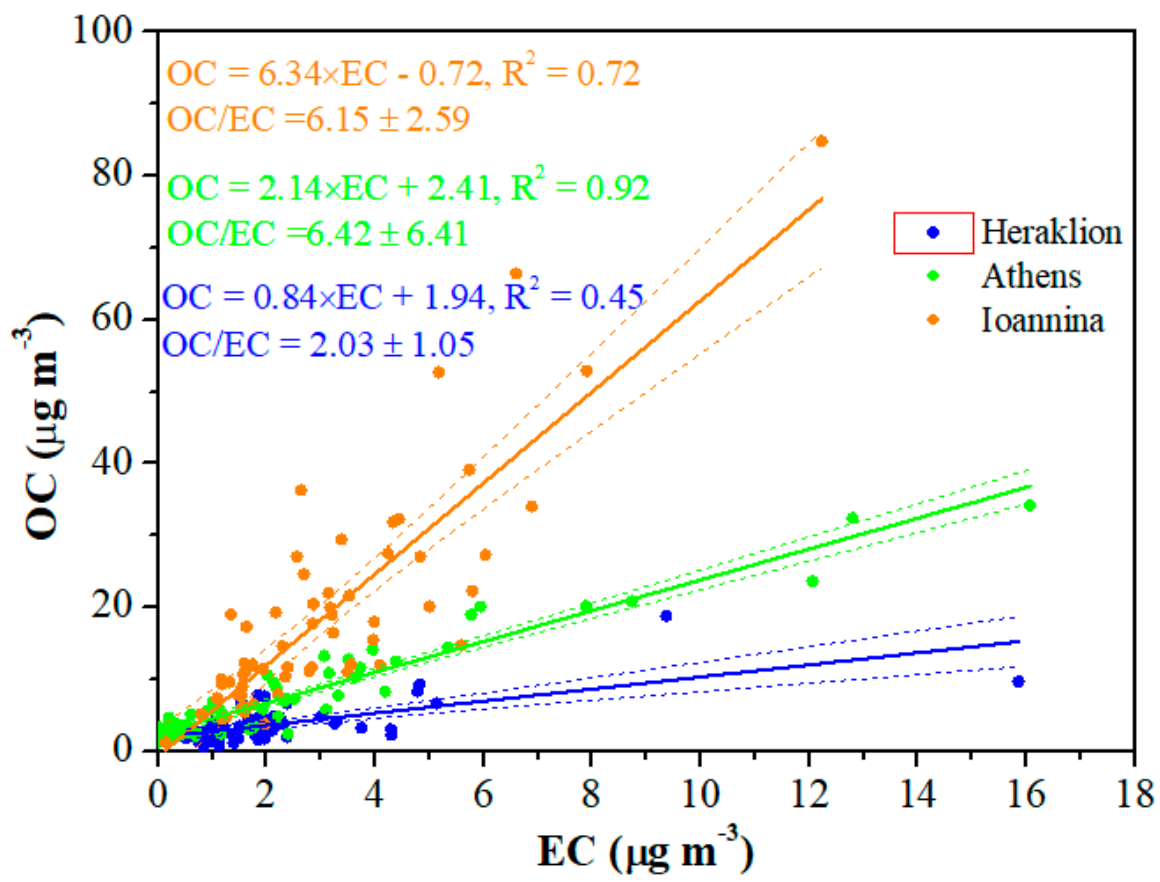

Figure 2. EC vs. OC concentrations in Heraklion, Athens, and Ioannina during the common period of measurements (January to February 2013).

\subsection{Influence of Meteorology}

The local meteorological conditions and boundary-layer dynamics play a major role in the concentrations of carbonaceous aerosols and in the relative contributions of the emission sources $[35,75,76]$. Table S2 summarizes the Pearson correlation coefficients $(r)$ between TSP, OC, and EC concentrations and meteorological variables (wind speed, temperature, rainfall) in Ioannina, where moderate (statistically significant at the $95 \%$ confidence level) negative associations are mostly seen. Figure 3 indicates a notable effect of the $\mathrm{T}_{\min }$ on $\mathrm{OC}$ and $\mathrm{EC}$ levels in Ioannina during winter, revealing an exponential increase at lower $\mathrm{T}_{\min }$, whereas in Heraklion, the concentration variability in the various $T_{\min }$ bins is less pronounced. This indicates a much lower dependence of carbonaceous aerosols on temperature compared to Ioannina, where the very low temperatures during winter nights favor the increased use of fireplaces and woodstoves for heating. Similarly, the highest hourly concentrations of submicron PM, OA, and BC in Athens have been reported to occur for temperatures below 8-9 ${ }^{\circ} \mathrm{C}$, indicating the excessive operation of fireplaces and woodstoves [77].

Precipitation washout was an effective cleansing mechanism, especially in Ioannina, with much lower concentrations being observed on rainy days (Figure S2). Mean dry/rainy ratios of 1.4 for TSP and 2.1 for EC were observed in Ioannina. In Heraklion the dry/rainy ratio was higher for TSP (1.6) than EC (1.1) but a marginal increase $\left(\approx 0.6 \mu \mathrm{g} \mathrm{m}^{-3}\right)$ was observed for OC during the rainy days, a somewhat unexpected finding, given the documented abundance of water-soluble organic aerosol in Crete [38]. 

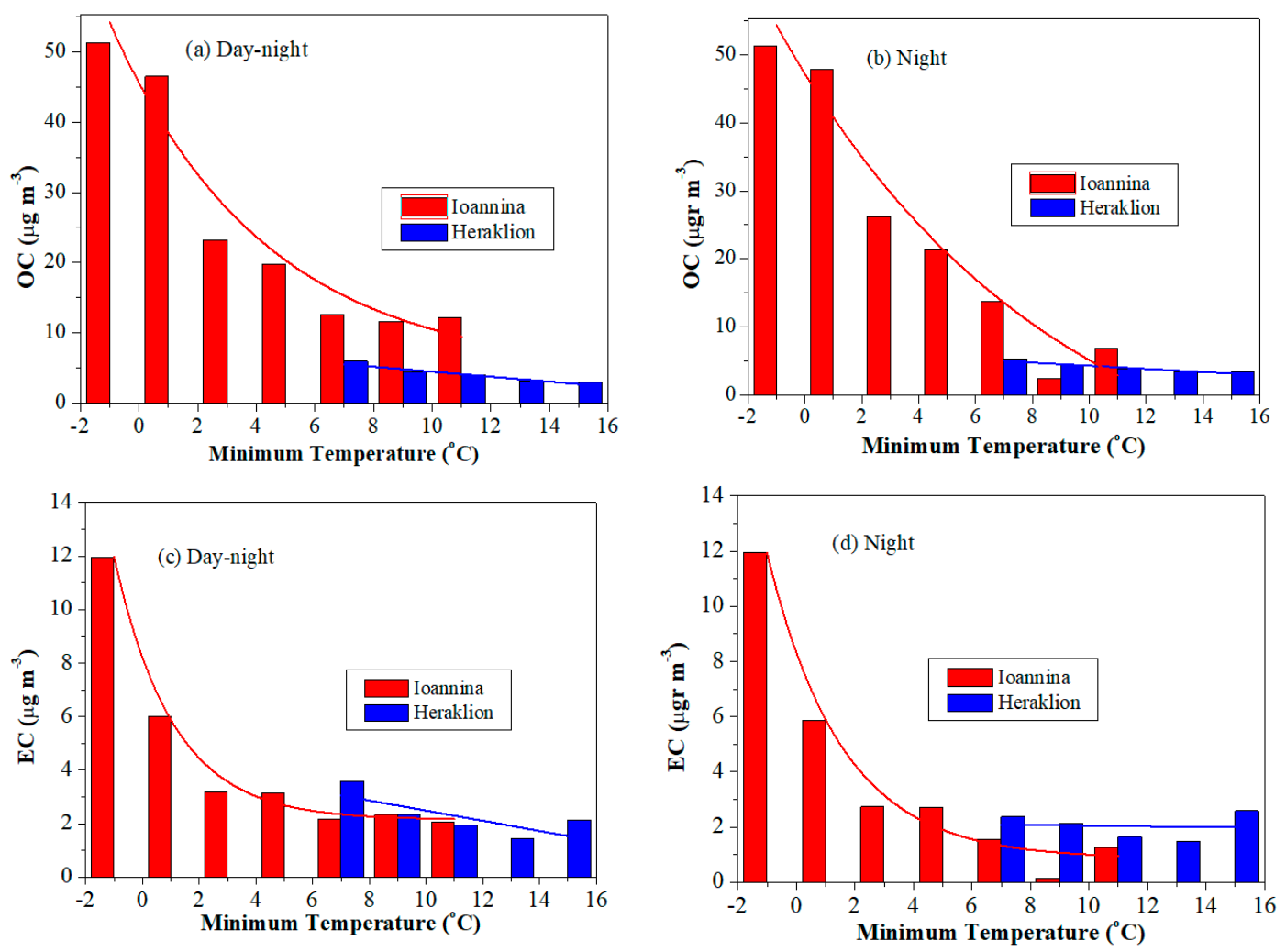

Figure 3. $\mathrm{OC}$ and EC concentrations averaged for $\mathrm{T}_{\min }$ bins in Ioannina and Heraklion for all and night-time only samples during the common measurement period. (a) OC day-night; (b) OC night; (c) EC day-night; (d) EC night.

\subsection{Association between Carbonaceous Aerosols and Inorganic Combustion Tracers}

The concentrations of the ionic species and carbonaceous aerosols for daytime and night-time winter TSP samples in Ioannina and Heraklion are shown in Figure S3. High levels of secondary inorganic ions $\left(\mathrm{NO}_{3}{ }^{-}, \mathrm{SO}_{4}{ }^{2-}\right)$ were observed in Ioannina, whereas in Heraklion, naturally-produced aerosols dominated (i.e., dust-coming from Sahara or re-suspended into the city, rich in $\mathrm{Ca}^{2+}$ and sea salt).

The correlation coefficients $(r)$ between OC, EC, and inorganic species in Ioannina and Heraklion are summarized in Tables S3 and S4, respectively. Regression analysis using non sea-salt potassium (nss- $\mathrm{K}^{+}=\mathrm{K}^{+}-0.037 \times \mathrm{Na}^{+}$) as a tracer is commonly used for qualitative evaluation of the BB contributions to aerosol concentrations [78,79]. Notwithstanding the higher probability of some coarse nss- $\mathrm{K}^{+}$crustal particles being quantified in the TSP fraction, strong associations were still observed with the carbonaceous components. OC was highly correlated with nss- $\mathrm{K}^{+}$in Ioannina $\left(R^{2}=0.76\right.$ and $R^{2}=$ 0.82 if only the winter night-time samples were considered), indicating the dominance of wood-burning emissions (Figure S4a). Lower correlations between nss- $\mathrm{K}^{+}$and EC $\left(R^{2}=0.54\right.$ and $R^{2}=0.61$ for winter-night only) suggest the importance of EC sources additional to wood-burning, such as use of fuel for heating and vehicular traffic (Figure S4b). Strong correlations were also registered between the primary BB-related components (nss- $\mathrm{K}^{+}, \mathrm{OC}, \mathrm{EC}$ ) and $\mathrm{NO}_{3}{ }^{-}$levels, suggesting the importance of local-scale emissions and processing (Table S3).

In contrast, in Heraklion, nss- $\mathrm{K}^{+}$was moderately related with OC and weakly with EC (Table S4), which were in turn mostly associated with $\mathrm{C}_{2} \mathrm{O}_{4}{ }^{2-}$ (Figure S4c,d). There was found to be an absence of correlation between $\mathrm{NO}_{3}{ }^{-}$and $\mathrm{OC} / \mathrm{EC}$, contrary to what has been observed in Ioannina and reported by previous studies in Athens [21,24], highlighting a lesser impact from local sources. The stronger correlations of $\mathrm{C}_{2} \mathrm{O}_{4}{ }^{2-}$ with OC and EC in Heraklion $(r=0.58$ and $r=0.72)$, indicate a larger influence from regional processes [80]. $\mathrm{C}_{2} \mathrm{O}_{4}{ }^{2-}$ exhibited significant correlations with $\mathrm{SO}_{4}{ }^{2-}$ 
at both sites, supporting its regional character and involvement in aqueous-phase chemistry [21,24]. Moreover, EC correlated well with nss-Ca ${ }^{2+}$ in Heraklion, indicating a common road traffic effect [81], as traffic-induced resuspension is a known source of calcium-rich particles [31].

In Ioannina, mean nss- $\mathrm{K}^{+} / \mathrm{EC}$ of $0.24 \pm 0.15$ and mean nss- $\mathrm{K}^{+} / \mathrm{OC}$ of $0.04 \pm 0.03$ were found, well within the limits reported for BB aerosols $[20,68,79,82]$. In Heraklion, the mean nss- $\mathrm{K}^{+} / \mathrm{EC}$ and nss- $\mathrm{K}^{+} / \mathrm{OC}$ ratios were estimated at $0.50 \pm 0.31$ and $0.28 \pm 0.19$, respectively, which are larger than those observed in Ioannina, probably due to the higher impact of crustal sources on nss- $\mathrm{K}^{+}$.

\subsection{Determination of Primary and Secondary Organic Carbon}

Consideration of the $5 \%$ and $25 \%$ OC/EC percentiles for all the available samples in Ioannina, resulted in (OC/EC) pri ratios of 1.61 and 1.89, respectively. In contrast, the MRS method (Figure S1) estimated a much higher (OC/EC) pri of 6.10 (5.96 for daytime samples, $n=35$, and 6.05 for night-time samples, $n=72$ ). It appears that the MRS method can be significantly affected by the large $\mathrm{BB}$ concentrations in the determination of the $(\mathrm{OC} / \mathrm{EC})_{\text {pri, }}$, whereas the $5 \%$ percentile approaches the ratio from primary fossil-fuel emissions $(\mathrm{OC} / \mathrm{EC})_{\mathrm{ff}}[49]$. On the contrary, a much lower $(\mathrm{OC} / \mathrm{EC})_{\text {pri }}$ value of 1.21 was estimated via the MRS for the non-winter $24 \mathrm{~h}$ samples $(n=20)$ when the effect of BB was almost eliminated, highlighting the effect of traffic. Therefore, season-specific (OC/EC) pri values were used in Ioannina [73]. In Heraklion, the $5 \%$ and $25 \%$ OC/EC percentiles resulted in (OC/EC) pri ratios of 0.61 and 0.58 , respectively, whereas the MRS method gave a comparable value of 0.84 (Figure S1), characteristic for roadway tunnels [49]. In Athens, the MRS method provided a primary ratio of 2.14, very close to those estimated by the $5 \%$ and $25 \%$ percentile methods ( 2.03 and 2.28 , respectively). Results from the SOC and POC estimations using the above (OC/EC) pri ratios are shown in Figure 4.
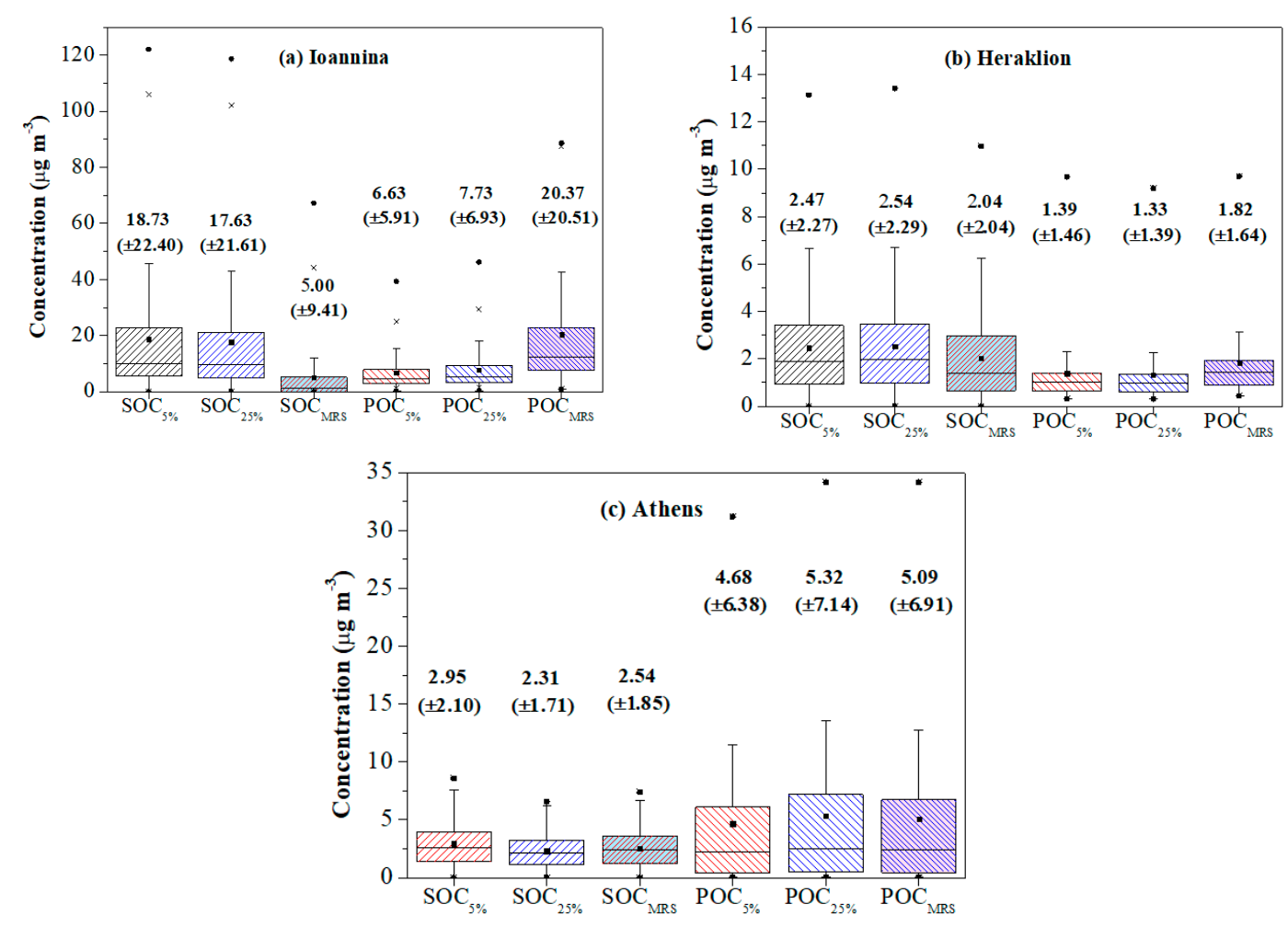

Figure 4. SOC and POC concentrations (box-whisker plots) in Ioannina (a), Heraklion (b), and Athens (c), using the $5 \%$ percentile, $25 \%$ percentile, and MRS method. Mean values \pm 1 standard deviation are also displayed.

In Ioannina, the implementation of the MRS method resulted in an average SOC concentration of $5.00 \pm 9.41 \mu \mathrm{g} \mathrm{m}^{-3}$ (Figure 4), corresponding to $20 \%$ of the total OC during the whole period (Table 1). 
In contrast, SOC dominated non-winter samples (53\%), indicating an increased photochemical production during the warm period of the year. On the opposite side, the $5 \%$ and $25 \%$ percentile methods resulted in more than three times higher SOC concentrations $\left(\approx 17.6-18.7 \mu \mathrm{g} \mathrm{m}^{-3} ; 69-74 \%\right.$ of the total OC). The two approaches led to contrasting results in Ioannina, due to the largely different $(\mathrm{OC} / \mathrm{EC})_{\text {pri }}$ ratios selected. In Heraklion, the percentile and MRS methods led to comparable results, demonstrating a prevalence of SOC (53-66\%). Previous studies in Crete support the fact that a significant fraction of OC is water-soluble and of secondary origin, with potential influence on chemical reactions and aerosol-cloud interactions [83,84]. In Athens, the results show higher wintertime POC contributions (63-70\%) and marginal differences between the methods. However, wintertime SOC levels are not negligible, indicating significant night-time formation processes including reactions with nitrate radicals $[36,85]$. A comparison between the SOC estimates by the percentile and MRS methods revealed high correlations in Heraklion (slopes $=1.10, R^{2}=0.99$ ) and Athens (slopes $=0.90,1.08 ; R^{2}=$ $0.92,0.97$, respectively) (Figure S5). In Ioannina, the slope (1.92-1.96), $R^{2}(0.69)$, and intercept (8.1-8.9) values are indicative of the deviation between the estimates provided by the MRS and percentile methods (Figure S5).

The percentage contributions of POC, SOC (based on MRS estimates), and EC components to total carbon (TC) in Ioannina, Heraklion, and Athens are summarized in Table 2. In Ioannina, POC dominated with an average fraction of $69 \%$, increased to $71.1 \%$ for the winter samples. However, for non-winter samples, SOC prevailed (38.4\%) against $33.4 \%$ for POC and $28.2 \%$ for EC. In contrast, in Heraklion, EC displayed the largest contribution to the TC mass with fractions of $37-38 \%$, whereas SOC contributed $31 \%$ to $35 \%$ and POC $28 \%$ to $31 \%$, with marginal differences between day and night. In Athens, POC accounted for half the TC (50.5\%), along with comparable contributions from SOC (25.3\%) and EC $(24.2 \%)$. During the daytime, the SOC fraction increased (31.3\%), whereas the EC fraction remained mostly unchanged.

Table 2. Percentage contribution of POC, SOC (estimated via MRS), and EC to the total carbon (TC) mass $(\mathrm{TC}=\mathrm{OC}+\mathrm{EC})$ in Ioannina, Heraklion, and Athens for various sampling periods.

\begin{tabular}{|c|c|c|c|c|c|c|c|c|c|c|c|}
\hline \multicolumn{4}{|c|}{ Ioannina } & \multicolumn{4}{|c|}{ Heraklion } & \multicolumn{4}{|c|}{ Athens } \\
\hline & $\begin{array}{c}\text { POC } \\
(\%)\end{array}$ & $\begin{array}{c}\text { SOC } \\
(\%)\end{array}$ & $\begin{array}{c}\text { EC } \\
(\%)\end{array}$ & & $\begin{array}{c}\text { POC } \\
(\%)\end{array}$ & $\begin{array}{c}\text { SOC } \\
(\%)\end{array}$ & $\begin{array}{l}\text { EC } \\
(\%)\end{array}$ & & $\begin{array}{c}\text { POC } \\
(\%)\end{array}$ & $\begin{array}{l}\text { SOC } \\
(\%)\end{array}$ & $\begin{array}{l}\text { EC } \\
(\%)\end{array}$ \\
\hline All & 69.0 & 17.0 & 14.0 & All & 29.5 & 33.2 & 37.3 & All & 50.5 & 25.3 & 24.2 \\
\hline Winter & 71.1 & 15.7 & 13.2 & Night & 27.8 & 35.3 & 36.9 & Night & 51.8 & 23.6 & 24.6 \\
\hline Non-winter & 33.4 & 38.4 & 28.2 & Day & 31.5 & 30.8 & 37.7 & Day & 46.1 & 31.3 & 22.6 \\
\hline Night & 69.2 & 18.6 & 12.2 & & & & & & & & \\
\hline Day & 79.9 & 2.5 & 17.6 & & & & & & & & \\
\hline
\end{tabular}

The estimated SOC contributions from past studies are largely contingent on the area characteristics and the measurement period. Grivas et al. [36] estimated average contributions of SOC to OC in the range of $28 \%$ to $40 \%$ in central Athens in 2003, depending on the period of the year and time of the day using the $(\mathrm{OC} / \mathrm{EC})_{\min }$ approach. Through an alternative technique (orthogonal regression based on OC/EC percentiles), taking also into account the intercept in the OC/EC relationship, they estimated a SOC/OC fraction of $21 \%$ (cold period) and $30 \%$ (warm period), indicating the sensitivity of the EC-tracer method on the selection of the primary ratio. These results are in the same direction with the current estimation of higher POC than SOC in central Athens, although, in the decade between the two studies, the main generating process of primary emissions has shifted from traffic to biomass burning [23]. On the contrary, at a suburban background site (Penteli) in Athens, Paraskevopoulou et al. [20] estimated a much higher average SOC fraction of 75\% $\pm 6 \%$ to the $\mathrm{PM}_{2.5}-\mathrm{OC}$ mass during 2008-2013. In Thessaloniki, average SOC fractions ranging from $35 \%$ to $55 \%$ for $\mathrm{PM}_{10}$ samples and from $39 \%$ to $54 \%$ for $\mathrm{PM}_{2.5}$ samples have been reported [37].

In general, the SOC/OC fraction, calculated with the EC-tracer approach, decreases in urban areas - even more at locations impacted by traffic — where fresh emissions are abundant, whereas it 
increases in remote areas with enhanced regional aerosol background (e.g., 70-80\% in Finokalia, Crete; [13]). High SOC contributions are typically observed in Southern European cities, favored by the warm climate and the strong insolation, which promote photo-oxidation processes. Using the (OC/EC) $\min$ approach, SOC/OC ratios of $42 \%$ in Oporto [52] and $47 \%$ in Toulouse [86] have been reported. Galindo et al. [87] found annual-mean contributions (38\%) of SOC to OC for $\mathrm{PM}_{10}$ samples in urban Elche, Spain, whereas a 50\% SOC fraction to OC mass of $\mathrm{PM}_{2.5}$ and $\mathrm{PM}_{10}$ samples was found in Lecce, Italy [88]. Conversely, estimated SOC concentrations of only $16-21 \%$ of OC mass in $\mathrm{PM}_{10}$ samples were estimated at three sites in Berlin, Germany, for the BB-active period [89]. These findings indicate a north-south gradient in SOC contributions in Europe, related to climatic conditions favoring the generation or organic compounds that undergo gas-to-particle conversion. This pattern can be replicated in a much smaller geographical scale, as it is indicated by the large difference between the mountainous and insular environments of Ioannina and Heraklion. In this case, the pattern was produced by the intensification of biomass burning in the harsh winter conditions versus the continued generation of SOC during winter in mild weather.

In Southeastern Asian cities, where much higher levels of carbonaceous aerosols are observed, SOC contributed to $43-49 \%$ of total $\mathrm{PM}_{2.5}$-OC in urban Delhi [51,90], and accounted for $18 \%, 25 \%$, and $60 \%$ of OC at traffic, rural, and remote sites, respectively, in Agra, India [91]. Reasonable results and variability patterns are still produced when the EC-tracer methodology is applied on data from TSP samples. For example, annual average SOC fractions in the range of $49 \%$ to $55 \%$ were estimated near Agra, India, and decreased to 39\% for samples highly affected by BB during wintertime [59].

The strong correlations $\left(R^{2}=0.74,0.57\right)$ between POC estimated with MRS and $5 \%$ percentile methods and nss- $\mathrm{K}^{+}$in Ioannina verify that the major part of POC should be attributed to BB emissions, contrary to Heraklion, where the respective correlations were found to be very weak $\left(R^{2}=0.09,0.06\right)$ due to the smaller impact from BB (Figure 5). Similarly, no correlation $\left(R^{2}=0.07\right)$ was noticed between POC and nss- $\mathrm{K}^{+}$regarding the non-winter samples in Ioannina. Table 3 summarizes the correlations between SOC, POC, and selected particle components. POC ${ }_{\text {MRS }}$ calculations revealed a stronger association with nss- $\mathrm{K}^{+}$in Ioannina compared to $\mathrm{POC}_{5 \%}$, indicating a better representation of primary emissions from wood combustion (Figure $5 \mathrm{a}, \mathrm{b}$ ), whereas the high correlation between nss- $\mathrm{K}^{+}$and $\mathrm{SOC}_{25 \%}(r=0.85$; Table 3$)$ suggests that the percentile method misrepresents BB-related POC as SOC. The high POC values are mostly associated with increased SOC and large nss- $\mathrm{K}^{+}$concentrations in Ioannina (Figure $5 \mathrm{a}, \mathrm{b}$ ), indicating concurrent presence of primary and rapidly-processed secondary aerosols related to BB $[33,42,92,93]$. The correlation between POC and SOC in Ioannina was higher for the $5 \%$ percentile $(r=0.73)$ against $r=0.57$ for MRS, and similar results were observed in Athens, with a $\mathrm{POC}_{5} \%$ vs. SOC $5 \%$ correlation of $r=0.77$, against $r=0.51$ for MRS (not shown). In addition, $\mathrm{SOC}_{\text {MRS }}$ and

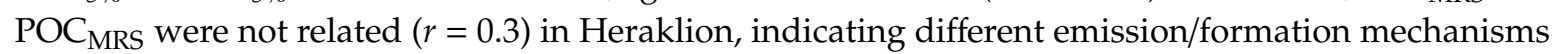
and SOC of regional origin. Therefore, it appears that in sites not excessively influenced by primary BB emissions, MRS seems to provide more robust POC and SOC estimates and differentiation [41], as the percentile methods result in consistently high POC-SOC correlations.

Table 3. Pearson correlation coefficients $(r)$ for comparisons of POC and SOC estimated with the MRS method against carbonaceous aerosols and ionic species. The asterisk $\left(^{*}\right)$ refers to correlations with $\mathrm{SOC}_{25 \%}$ in Ioannina.

\begin{tabular}{|c|c|c|c|c|c|c|c|c|}
\hline Component & OC & EC & $\mathrm{NO}_{3}{ }^{-}$ & nss-SO ${ }_{4}{ }^{2-}$ & nss-K ${ }^{+}$ & $\mathrm{C}_{2} \mathrm{O}_{4}{ }^{2-}$ & $\mathrm{NH}_{4}{ }^{+}$ & nss-Ca ${ }^{2+}$ \\
\hline POC $_{\text {IOA }}$ & 0.96 & 0.88 & 0.70 & 0.62 & 0.86 & 0.39 & 0.53 & 0.34 \\
\hline SOC IOA $_{\text {IOA }}$ & 0.78 & 0.35 & 0.32 & 0.38 & 0.63 & 0.15 & 0.28 & 0.11 \\
\hline SOC IOA * $^{*}$ & 0.98 * & 0.71 * & 0.58 * & 0.55 * & $0.85 *$ & $0.32 *$ & 0.48 * & 0.22 * \\
\hline POC $_{\text {HER }}$ & 0.76 & 0.98 & 0.02 & 0.27 & 0.34 & 0.66 & 0.19 & 0.55 \\
\hline SOC $_{\text {HER }}$ & 0.85 & 0.19 & -0.11 & 0.15 & 0.52 & 0.12 & 0.37 & -0.34 \\
\hline POC $_{\text {ATH }}$ & 0.96 & 0.99 & 0.73 & 0.47 & 0.72 & 0.41 & 0.39 & -0.06 \\
\hline SOC $_{\text {ATH }}$ & 0.36 & 0.05 & -0.18 & 0.38 & 0.01 & 0.12 & 0.57 & -0.16 \\
\hline
\end{tabular}



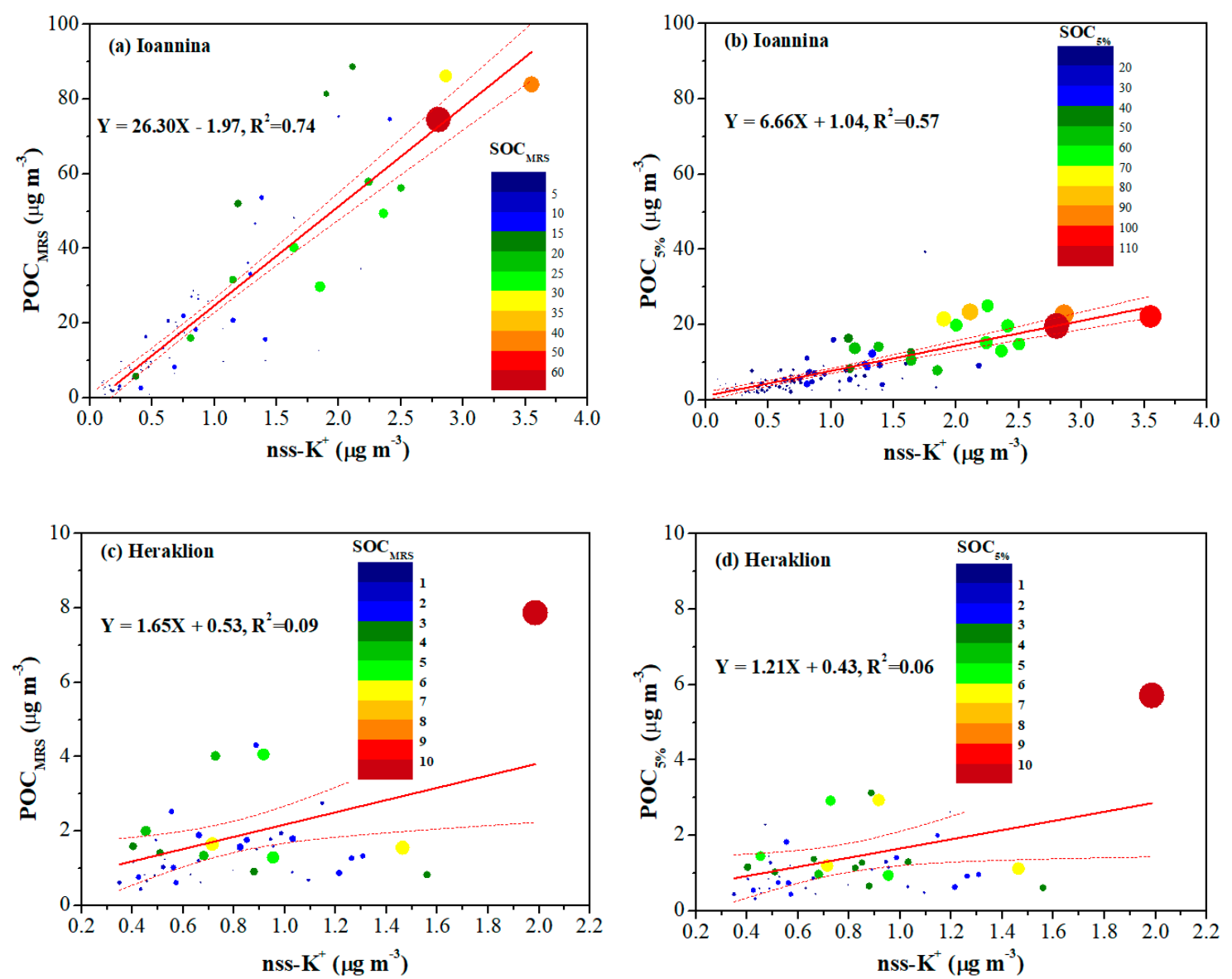

Figure 5. Correlations between nss- $\mathrm{K}^{+}$and POC estimates via the MRS and 5\% percentile methods in Ioannina $(\mathbf{a}, \mathbf{b})$ and Heraklion (c,d), as a function of the respective SOC estimates.

\subsection{Differences in SOC Estimation Using the MRS and Percentile Methods}

This section explores the differences in SOC estimates via the MRS and percentile methods and associates them with BB emissions. Similar to the present cases, using the percentiles $(10 \%, 20 \%)$ resulted in lower (OC/EC) pri ratios compared to the MRS method in Guangzhou, China [42]. Wu and $\mathrm{Yu}$ [41] showed that the difference in (OC/EC) pri estimated with the two approaches decreased with an increase in SOC fraction. This observation was verified in the current analysis, as the lowest deviations in Heraklion were associated with the highest SOC fraction among sites. On the other hand, the difference is accentuated in Ioannina due to the intensity of BB emissions. In this site, the results are differentiated from the studies in Guangzhou [41,42], where the BB activities are not so pronounced.

The MRS method assumes the absence of correlation between SOC and EC. A basic limitation of the method is that this assumption can be violated if a significant part of SOC is formed from VOCs co-emitted with EC [42,94]. This part of SOC (hereafter called SOC a $_{\mathrm{a}}$ cannot be isolated from POC by the MRS method, which estimates only the SOC part that is unrelated to EC and, therefore, can partially underestimate the SOC concentrations. Moreover, the MRS method might fail to correctly classify the processed organic aerosols as SOC (e.g., from photo-oxidation or regional transport) that correspond to OC/EC ratios lower than the primary in areas with intense BB emissions. On the other hand, the SOC obtained from the percentile methods would correspond to an amount with a significant influence from primary BB emissions, leading to an important $\mathrm{SOC}$ overestimation (Figure 4), especially in environments impacted by $\mathrm{BB}$, as the $(\mathrm{OC} / \mathrm{EC})_{\text {pri }}$ in this case is mostly related to vehicular emissions. In addition, $\mathrm{POC}$ emissions from non-combustion sources are not accounted for by either of the methods. 
The difference between the SOC estimates from the percentile and MRS methods is indicative of the SOC fraction produced from combustion sources after fast oxidation of precursors from both fossil-fuel combustion and BB [42]. A strong correlation $\left(R^{2}=0.72\right)$ was calculated between nss- $\mathrm{K}^{+}$ and the difference between $\mathrm{SOC}_{5 \%}$ and $\mathrm{SOC}_{\mathrm{MRS}}$ (Figure 6), whereas the mean difference $\left(13.7 \mu \mathrm{g} \mathrm{m}^{-3}\right.$ ) increased to $19.5 \mathrm{\mu g} \mathrm{m}^{-3}$ for the winter night-time samples in Ioannina. Furthermore, the larger differences were found to be strongly related to higher OC concentrations. This indicates that the secondary particles classified in the estimated $\mathrm{POC}_{\mathrm{MRS}}$ are most likely related to rapidly oxidized OC from BB emissions $[95,96]$. Conversely, these particles are captured in $\mathrm{SOC}_{5 \%}$. Stavroulas et al. [33] found a large fraction of SV-OOA in Athens that was attributed to processed BBOA, especially during winter nights, which indicated that BB may substantially complicate the SOC estimations.

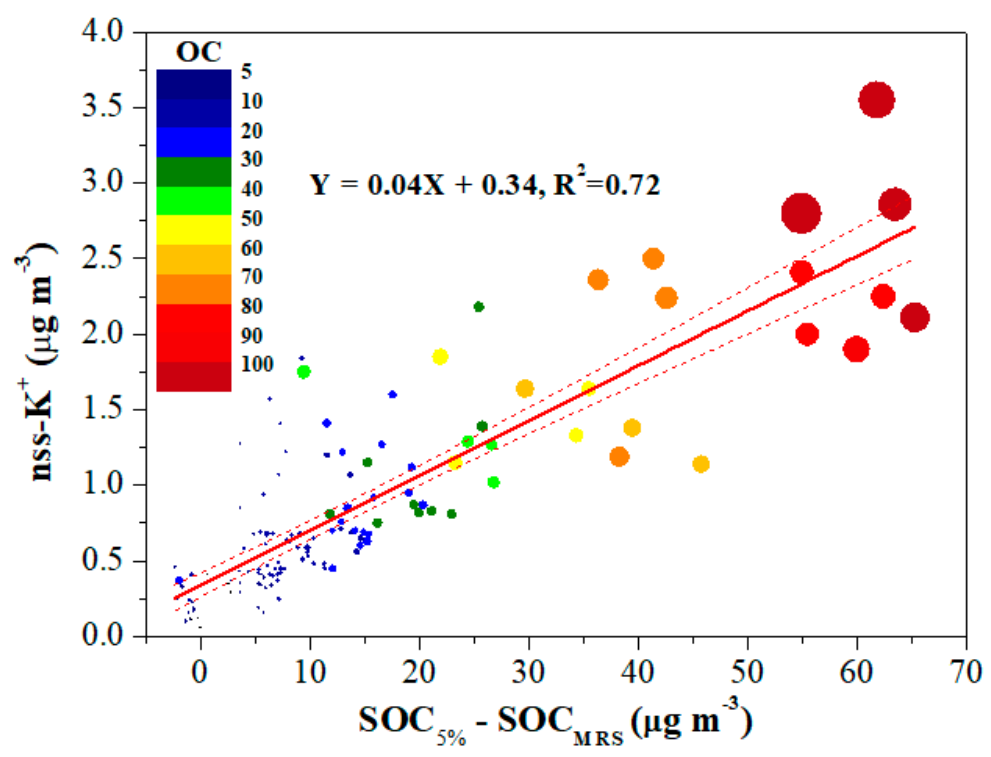

Figure 6. Correlation between the differences in SOC concentrations deriving from the $5 \%$ percentile and MRS methods with nss- $\mathrm{K}^{+}$as a function of the OC concentration (colored scale) in Ioannina. The slight negative differences correspond to non-winter samples.

\subsection{Comparison of EC-tracer SOC Estimates with Carbonaceous Components from Online Measurements}

For a more detailed investigation of the differences in SOC estimates between the MRS and percentile methods and to associate them with primary and oxygenated organics, we applied both methods for SOC estimates in Athens during a period (December 2016 to January 2017) with concurrent measurements of $\mathrm{OC}, \mathrm{EC}$, and ions from $\mathrm{PM}_{2.5}$ filter samples, of black carbon $\left(\mathrm{BC}, \mathrm{BC}_{\mathrm{bb}}, \mathrm{BC}_{\mathrm{ff}}\right)$ from an aethalometer (AE-33) [34], and of ACSM-derived organic aerosol components [33]. In this period, the MRS method estimated an (OC/EC) pri of 1.78 , whereas the $5 \%$ and $25 \%$ percentiles resulted in $(\mathrm{OC} / \mathrm{EC})_{\text {pri }}$ ratios of 0.96 and 1.37 , respectively, indicating temporally varying $(\mathrm{OC} / \mathrm{EC})_{\text {pri }}$.

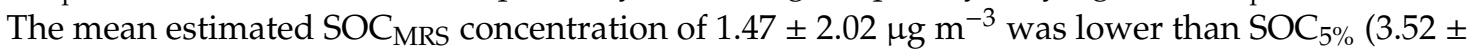
$\left.4.46 \mu \mathrm{g} \mathrm{m}^{-3}\right)$ and $\mathrm{SOC}_{25 \%}\left(2.41 \pm 3.13 \mu \mathrm{g} \mathrm{m}^{-3}\right)$. Strong positive associations were observed between POC and BBOA $\left(R^{2}=0.64-0.68\right)$, and $\mathrm{HOA}\left(R^{2}=0.66-0.69\right)$, with the higher correlations corresponding to estimates from MRS. On the other hand, the SOC estimates were also significantly correlated with $\mathrm{BBOA}$, with the $\mathrm{SOC}_{\mathrm{MRS}}$ displaying the lowest $R^{2}=0.55$, against $R^{2}=0.75$ for $\mathrm{SOC}_{5 \%}$, and $R^{2}=0.69$ for $\mathrm{SOC}_{25 \%}$. This indicates that SOC estimates from the percentile methods had a higher probability of including primary emissions from BB than the estimates from the MRS. This was also verified (Figure $\mathrm{S6}$ ) from the much stronger correlations $\left(R^{2}=0.80\right)$ of the percentile-derived SOC-compared to MRS-derived SOC $\left(R^{2}=0.39\right)$ - with Delta-C $\left(\mathrm{BC}_{370}-\mathrm{BC}_{880}\right)$, which can be used as a semi-quantitative indicator of wood combustion [34,97]. In addition, $\mathrm{SOC}_{\mathrm{MRS}}$ was-expectedly-not correlated with HOA $\left(R^{2}=0.03\right)$, as opposed to the moderate positive association for the $\mathrm{SOC}_{5}$ and $\mathrm{SOC}_{25}$ estimates 
$\left(R^{2}=0.16-0.34\right)$. This suggests that the high $\mathrm{SOC}_{5 \%}$ (and $\left.\mathrm{SOC}_{25 \%}\right)$ values can receive an important contribution from primary (fossil fuel and $\mathrm{BB}$ ) emissions in fractions much larger than those in the MRS method and, therefore, the lowest percentile method appears to be less reliable for SOC estimates, as the primary fossil-fuel and BB emissions in an urban area are temporally variable [42,49]. This was further justified by the much higher correlation between $\mathrm{SOC}_{5 \%}$ and $\mathrm{BC}_{\mathrm{bb}}\left(R^{2}=0.77\right)$ as opposed to $\mathrm{SOC}_{25 \%}\left(R^{2}=0.57\right)$ and $\mathrm{SOC}_{\mathrm{MRS}}\left(R^{2}=0.32\right)$ correlations with $\mathrm{BC}_{\mathrm{bb}}$. In addition, a significant correlation between $\mathrm{SOC}_{5 \%}$ and $\mathrm{BC}_{\mathrm{ff}}$ was found $\left(R^{2}=0.38\right)$, whereas $\mathrm{SOC}_{\mathrm{MRS}}$ was not related to $\mathrm{BC}_{\mathrm{ff}}$ $\left(R^{2}=0.03\right)$, justifying the minimal correlation between SOC and vehicular/oil-combustion EC in the MRS method [42].

Figure 7 shows the correlations between POC-SOC estimates with the SV-OOA component and $\mathrm{BC}_{\mathrm{bb}}$ in Athens. The $\mathrm{POC}_{\mathrm{MRS}}$ was strongly related to SV-OOA, indicating a higher probability of including a part of SV-OOA in the primary component. This constitutes a bias in the MRS estimates in highly BB-laden atmospheres, as a large fraction of SV-OOA corresponding to $\mathrm{SOC}_{\mathrm{a}}$ [42], was misclassified as POC. Furthermore, as mentioned above, because of the higher (OC/EC) pri determined from the MRS method at sites highly-impacted by BB emissions, some non-BB related secondary particles were also captured in the POC. These two biases resulted in POC overestimation, as was most likely the case in Ioannina (Figure 4).
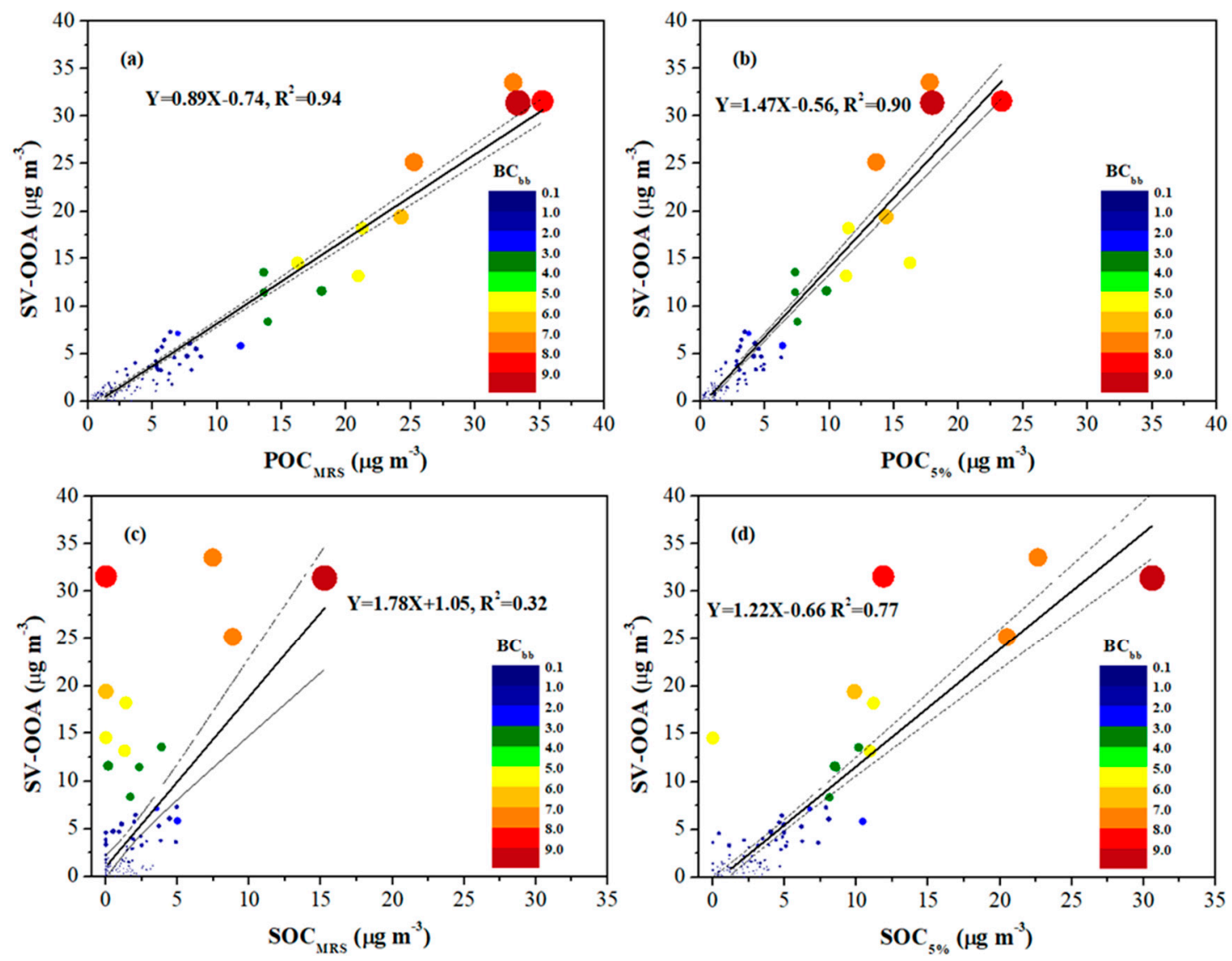

Figure 7. Correlation between POC (a,b) and SOC (c,d) estimates from the MRS $(\mathbf{a}, \mathbf{c})$ and $5 \%(\mathbf{b}, \mathbf{d})$ percentile methods against the semi-volatile oxygenated organic aerosol (SV-OOA) component in Athens during December 2016 to January 2017. The colored scale corresponds to $\mathrm{BC}_{\mathrm{bb}}$ deriving from aethalometer (AE-33) measurements at the same site.

On the other hand, $\mathrm{SOC}_{\mathrm{MRS}}$ was much less related to SV-OOA compared to $\mathrm{SOC}_{5 \%}$ (Figure 7c,d) and, moreover, the latter displayed a similar mean concentration $\left(3.52 \pm 4.46 \mu \mathrm{g} \mathrm{m}^{-3}\right)$ with SV-OOA $\left(3.63 \pm 6.17 \mu \mathrm{g} \mathrm{m}^{-3}\right)$. However, the excellent correlations of SV-OOA with $\mathrm{BC}_{\mathrm{bb}}\left(R^{2}=0.96\right)$ and BBOA 
$\left(R^{2}=0.70\right)$ suggest that the largest fraction of the SV-OOA was a fast-oxidized component from RWB emissions $[33,35]$ that was considered as POC in the MRS estimates.

A mean ratio of ACSM-organics/OC of 1.59 was calculated, similar to $\mathrm{OM} / \mathrm{OC}=1.5 \pm 0.1$ that was reported in Athens during January to February 2013 [27]. This ratio was expected to be higher ( $\approx 1.8-2.1)$ for the oxygenated components (SV-OOA and LV-OOA), as it has been documented in remote areas dominated by processed aerosols $[98,99]$. Using these values, the OC equivalent concentration of the [SV-OOA + LV-OOA] components was estimated as 3.48 and $3.01 \mathrm{\mu g} \mathrm{m}^{-3}$, respectively, close to the SOC $_{5 \%}$ estimates $\left(3.52 \mu \mathrm{g} \mathrm{m}^{-3}\right)$, but significantly higher than $\operatorname{SOC}_{\text {MRS }}\left(1.47 \mu \mathrm{g} \mathrm{m}^{-3}\right)$. The analysis showed that $\mathrm{SOC}_{\mathrm{MRS}}$ mean concentration was close to the $\mathrm{OC}$ mass corresponding to the LV-OOA component $\left(1.25 \mu \mathrm{g} \mathrm{m}^{-3}\right.$ using the higher ratio of 2.1), implying that the processed aerosols were to a large extent captured by this method. The estimated OC mass from SV-OOA was very similar to the mean difference of $\mathrm{SOC}_{5 \%}$ and $\mathrm{SOC}_{\mathrm{MRS}}\left(2.05 \mu \mathrm{g} \mathrm{m}^{-3}\right)$, which corresponded to $32 \%$ of the OC mass, a fraction similar to that of SV-OOA to total organic mass derived from ACSM data (35\%). Furthermore, there was a strong correlation $\left(R^{2}=0.92\right.$, slope: $\left.0.96-1.12\right)$ between $\left[\mathrm{SOC}_{5 \%}-\mathrm{SOC}_{\mathrm{MRS}}\right.$ ] and the OC mass of the SV-OOA for the 1.8 and 2.1 scaling factors (Figure $8 \mathrm{a}, \mathrm{b}$ ), implying that the $\mathrm{SOC}_{\mathrm{MRS}}$ cannot adequately represent the $\mathrm{OC}$ mass from fast-oxidized BB emissions.
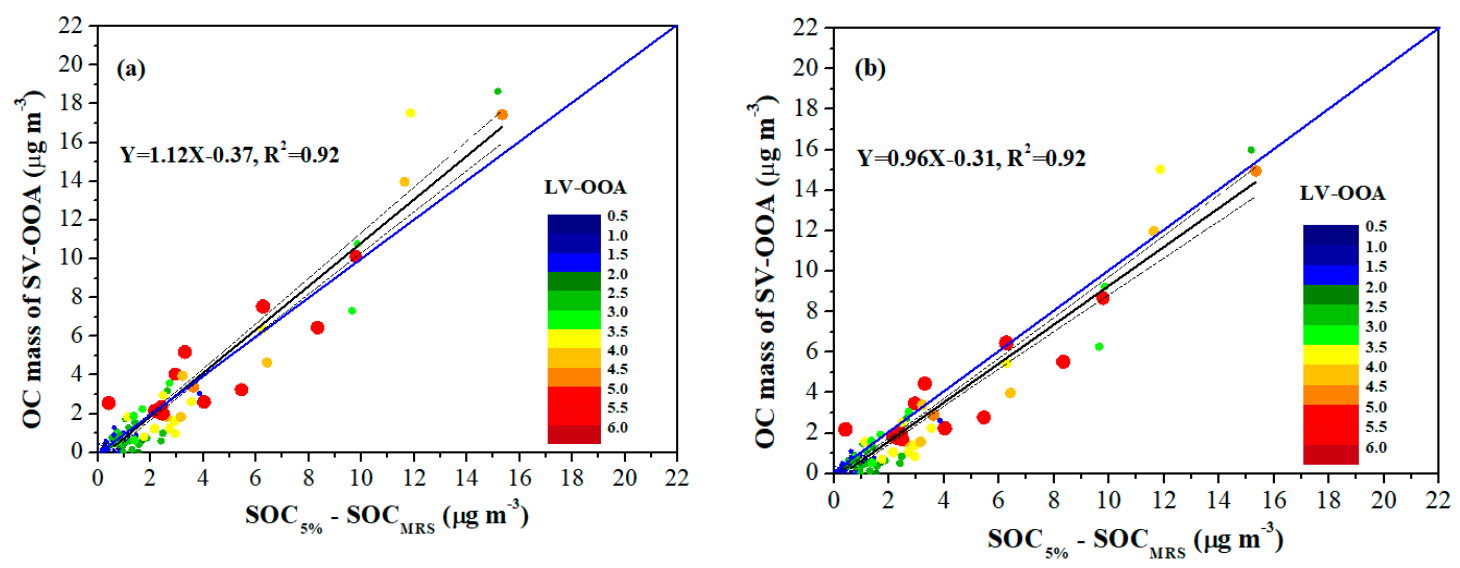

Figure 8. Correlations between the differences in SOC concentrations derived via the $5 \%$ percentile and MRS methods and the estimated OC mass of the SV-OOA using a conversion factor of OA/OC = 1.8 (a) and $\mathrm{OA} / \mathrm{OC}=2.1(\mathbf{b})$, as a function of the low-volatility oxygenated organic aerosol (LV-OOA) (colored scale) in Athens. The blue line corresponds to "1:1".

\subsection{Fossil Fuel vs. Biomass Burning POC}

POC originates from various primary combustion sources such as vehicular emissions, BB, and cooking [100], and a quantitative breakdown of its components can provide essential knowledge about the emission sources and their contribution to atmopsheric chemistry. Here, an attempt to roughly evaluate the POC fractions related to fossil-fuel combustion (FF) and biomass burning (BB) is presented, using $\mathrm{K}_{\mathrm{bb}}{ }^{+}$as BB tracer [79,87]. The POC component, as estimated with the MRS method, can be decomposed to its major sources as

$$
\mathrm{POC}=\mathrm{POC}_{\mathrm{bb}}+\mathrm{POC}_{\mathrm{ff}}+\mathrm{POC}_{\text {non-comb }} .
$$

Because in the implementation of the MRS method at the three sites, the non-combustion sources were considered negligible, the following relations were used to evaluate the contributions from $\mathrm{BB}$ and FF as

$$
\begin{gathered}
\mathrm{POC}_{\mathrm{bb}}=\left(\mathrm{OC} / \mathrm{K}_{\mathrm{bb}}{ }^{+}\right)_{\mathrm{pri}} \times \mathrm{K}_{\mathrm{bb}}{ }^{+} \\
\mathrm{POC}_{\mathrm{ff}}=\mathrm{POC}-\left(\mathrm{OC} / \mathrm{K}_{\mathrm{bb}}^{+}\right)_{\mathrm{pri}} \times \mathrm{K}_{\mathrm{bb}}{ }^{+}
\end{gathered}
$$


$\mathrm{K}_{\mathrm{bb}}{ }^{+}$is the potassium fraction that corresponds to BB emissions [21,24,79], whereas the $\left(\mathrm{OC} / \mathrm{K}_{\mathrm{bb}}{ }^{+}\right)_{\text {pri }}$ corresponds to the value leading to negligible correlation between fossil-fuel OC emissions $\left(\mathrm{POC}_{\mathrm{ff}}\right.$ ) and $\mathrm{K}_{\mathrm{bb}}{ }^{+}$(calculated in a procedure similar to the MRS method, which was also used for the determination of $\left.\left(\mathrm{OC} / \mathrm{K}_{\mathrm{bb}}{ }^{+}\right)_{\text {pri }}\right)$. For the estimation of $\mathrm{K}_{\mathrm{bb}}{ }^{+}$from $n s s-\mathrm{K}^{+}, \mathrm{Ca}^{2+}$ was used as a tracer for $\mathrm{K}^{+}$in the dust particles $\left(\mathrm{K}^{+}\right.$dust $)$. In Ioannina, the slope from the $\mathrm{nss}-\mathrm{K}^{+} / \mathrm{Ca}^{2+}$ linear regression $(0.04$, with $r=0.65)$ was calculated for the non-winter samples and was used to estimate the $\mathrm{K}^{+}$dust values, which were subtracted from the nss- $\mathrm{K}^{+}$to estimate the $\mathrm{K}_{\mathrm{bb}}{ }^{+}$concentrations [24,79]. In Ioannina, the primary ratio $\left(\mathrm{OC} / \mathrm{K}_{\mathrm{bb}}{ }^{+}\right.$) pri was estimated at 27 , and via Equation (5) the $\mathrm{POC}_{\mathrm{bb}}$ and $\mathrm{POC}_{\mathrm{ff}}$ components were calculated at $17.98 \mu \mathrm{g} \mathrm{m}^{-3}(77 \%)$ and $5.37 \mu \mathrm{g} \mathrm{m}^{-3}(23 \%)$, respectively, for the winter period. These fractions are comparable to the very high fractions reported for BB contributions to primary organic aerosols at alpine sites strongly impacted by RWB emissions [63,101]. The same technique was followed in Athens, where the $\mathrm{K}_{\mathrm{bb}}{ }^{+}$was estimated from the slope of the nss- $\mathrm{K}^{+} / \mathrm{Ca}^{2+}$ regression $(0.43$, with $r=0.62)$ using available data during the summer periods of 2014-2015 from the same site [24]. An $\left(\mathrm{OC} / \mathrm{K}_{\mathrm{bb}}{ }^{+}\right)_{\text {pri }}$ of 20 was estimated via the MRS method, resulting in $\mathrm{POC}_{\mathrm{ff}}=$ $60 \%$, against $\mathrm{POC}_{\mathrm{bb}}=40 \%$. This $\mathrm{POC}_{\mathrm{bb}}$ fraction is higher than the respective one in $\mathrm{BC}$ measured at the same site $\left(\mathrm{BC}_{\mathrm{bb}}\right.$ of $32 \%$ during the winters of 2015-2019 [34]), as BB generally promotes the OC emissions-relative to EC-in higher rates than fossil-fuel combustion $[49,65,102,103]$. Due to the unavailability of ionic species during the summer period that prevents $\mathrm{K}_{\mathrm{bb}}{ }^{+}$estimation, the method was not applied in Heraklion. Despite the assumptions and the increased uncertainties in applying this methodology on a limited number of samples, the results are quite reasonable regarding the much higher $\mathrm{POC}_{\mathrm{BB}}$ emissions and contribution in Ioannina compared to Athens. The estimation of the $\mathrm{K}_{\mathrm{bb}}{ }^{+}$ using $\mathrm{Ca}^{2+}$ as tracer for excluding the $\mathrm{K}_{\text {dust }}{ }^{+}$contains an additional degree of uncertainty. However, even considering the nss- $\mathrm{K}^{+}$as tracer (instead of $\mathrm{K}_{\mathrm{bb}}{ }^{+}$), the contributions were marginally different $\left(\mathrm{POC}_{\mathrm{bb}} / \mathrm{POC}=78 \%\right.$ in Ioannina and $44 \%$ in Athens).

An evaluation of this method was attempted by comparing the $\mathrm{POC}_{\mathrm{bb}}$ estimates (using the $\mathrm{K}_{\mathrm{bb}}{ }^{+}$ as tracer and the previously-derived $\mathrm{POC}_{\mathrm{MRS}}$ ) against the $\mathrm{BC}_{\mathrm{bb}}$ and $\mathrm{BBOA}$ concentrations in Athens during December 2016 to January 2017. The estimated POC $_{\mathrm{bb}}$ exhibited very strong correlations with $\mathrm{BC}_{\mathrm{bb}}\left(R^{2}=0.95\right)$ and BBOA $\left(R^{2}=0.84\right)$. It appears that the MRS method can be also applied for an empirical decomposition of $\mathrm{POC}$, resulting in reliable results in case of accurate determination of $\mathrm{K}_{\mathrm{bb}}{ }^{+}$, or other suitable BB tracers [42,79].

The recent review study by Srivastava et al. [104] describes the application of the most common methods for the SOC estimation, these being the EC-tracer method, chemical mass balance (CMB), SOA tracer method, and PMF. Several studies have also focused on the quantification of BB contributions to OC using different approaches such as regression with BB tracers such as levoglucosan [105-107] and radiocarbon analysis $[101,108]$. Recently, the use of $(\mathrm{OC} / \mathrm{CO})_{\text {pri }}$ as tracer and the application of the MRS method further improved the SOC estimates in urban environments with multiple emission sources [109]. However, results of BB contribution to POC using filter-based OC and EC data have been relatively sparse [79]. Chen et al. [110] followed an alternative approach to the EC-tracer method using different primary ratios for fossil fuel $(\mathrm{OC} / \mathrm{EC})_{\mathrm{ff}}$ and biomass burning $(\mathrm{OC} / \mathrm{EC})_{\mathrm{bb}}$, which were respectively multiplied with estimated $\mathrm{EC}_{\mathrm{ff}}$ and $\mathrm{EC}_{\mathrm{bb}}$ components to calculate $\mathrm{POC}_{\mathrm{ff}}$ and $\mathrm{POC}_{\mathrm{bb}}$ and, therefore, SOC at three sites in the Sichuan basin, China. They reported $\mathrm{POC}_{\mathrm{bb}}$ fractions in the range of $21.9 \%$ to $30.8 \%$ and SOC fractions of $24.6-26.7 \%$.

This alternative approach [110] was applied for $\mathrm{POC}_{\mathrm{bb}}$ and $\mathrm{POC}_{\mathrm{ff}}$ estimation in Athens during the period of December 2016 to January 2017. We utilized the lowest $5 \%$ percentile for the primary $(\mathrm{OC} / \mathrm{EC})_{\mathrm{ff}}$ value, as in Chen et al. [110]. For the primary $(\mathrm{OC} / \mathrm{EC})_{\mathrm{bb}}$ value, we used the OC/EC ratio (3.7) calculated in the profile of the biomass-burning source by the source apportionment analysis of Theodosi et al. [24] for $\mathrm{PM}_{2.5}$ at the same site during three winter periods between 2013 and 2016. To classify $\mathrm{EC}_{\mathrm{ff}}$ and $\mathrm{EC}_{\mathrm{bb}}$ components, we used the respective $\mathrm{BC}$ relative fractionation $\left(\mathrm{BC}_{\mathrm{ff}}, \mathrm{BC}_{\mathrm{bb}}\right)$ to obtain the corresponding $12 \mathrm{~h}$ values, taking into account the high degree of inter-dependence between BC and EC [34] and the very small fraction of non-EC light-absorbing $\mathrm{PM}_{2.5}$ at $880 \mathrm{~nm}$ [35]. 
In this way, a SOC fraction of $17 \%$ was obtained using the source-specific ratios approach against $23 \%$ from the MRS EC-tracer, whereas $\mathrm{POC}_{\mathrm{bb}} / \mathrm{OC}$ was estimated at $63 \%$ and $54 \%$ by the two methods, respectively. Chen et al. [110] also reported lower SOC estimates from this alternative approach compared to EC-tracer method. Overall, the two methods exhibited a discrepancy in the order of $5-10 \%$ in the estimations of the OC components, comparable to those observed between the different approaches in the EC-tracer method $[36,42,49,50]$.

\section{Conclusions}

Ambient particle samples collected in three Greek cities (Athens, Ioannina, Heraklion) during winter field campaigns were analyzed for carbonaceous aerosols (OC, EC) and major ions in order to examine the atmospheric composition and influence of wood-burning emissions. The results of this study revealed, for the first time, the contrasting atmospheric composition between the cold winter conditions in northwest continental Greece (Ioannina) and the mild weather, which prevails even during winter on the island of Crete (Heraklion) in the eastern Mediterranean. The mean concentrations of OC and EC were 25.37 and $4.14 \mu \mathrm{g} \mathrm{m}^{-3}$, respectively, in Ioannina-values much higher than in Heraklion, whereas mean concentrations of 7.63 and $2.44 \mu \mathrm{g} \mathrm{m}^{-3}$, respectively, were recorded in Athens. The observed mean OC levels in Ioannina (exceeding $25 \mathrm{\mu g} \mathrm{m}^{-3}$ ), which were associated with excessive winter-time biomass burning emissions, are severe and potentially hazardous for human health.

Winter-time OC/EC ratios displayed noTable Spatial variability, being higher in Ioannina (6.53) compared to Athens (6.42) and Heraklion (2.03). At all sites, POC and SOC estimates were retrieved using the EC-tracer method and specifically the MRS and lower percentile ( $5 \%$ and $25 \%$ ) approaches. Using the MRS method, higher POC fractions were calculated in Ioannina $(80 \%)$ and Athens $(67 \%)$ in comparison to Heraklion (47\%). Especially in Ioannina, the SOC estimation was largely dependent on the applied methodology, a fact attributed to the large impact of the enhanced BB emissions on both primary and secondary organic aerosols. The $5 \%$ and $25 \%$ percentiles method in Ioannina resulted in much higher SOC fractions of $69-73 \%$, which, however, included a significant portion of BB-related primary organic aerosols. This was supported by a high correlation $\left(R^{2}=0.73\right)$ between $\mathrm{SOC}_{5 \%}$ and nss- $\mathrm{K}^{+}$, whereas the $\mathrm{SOC}_{\mathrm{MRS}}$ was much less dependent on nss- $\mathrm{K}^{+}\left(R^{2}=0.40\right)$. On the other hand, the SOC fraction in Ioannina was underestimated by the MRS method, as it failed to classify as secondary the semi-volatile organic aerosols that are rapidly oxidized from the BB emissions and other secondary aerosols corresponding to OC/EC ratios lower than the high primary value. The results from comparisons with filter-based, light-absorption-based, and mass-spectrometric BB tracers proved that this part of less-oxidized OA was considered as POC by the MRS method. In Heraklion and Athens, the various methods resulted in much lower differences between the SOC and POC estimates among the methods, due to the relatively smaller impact of BB. In such cases, the EC-tracer methodology can provide reliable (especially in terms of temporal variability) categorization between primary and secondary OC components in the absence of aerosol mass spectrometric measurements, which are still rather costly and also face some uncertainties in the statistical source apportionment for the organic aerosol components.

Although the MRS method effectively excludes POC from SOC estimates, it may underestimate the SOC component in environments highly impacted by BB emissions. The decomposition of POC into its $\mathrm{BB}$ and fossil-fuel components was attempted for the first time, using the $\mathrm{OC} / \mathrm{K}_{\mathrm{bb}}{ }^{+}$ratio as tracer. In general, the $\mathrm{POC}_{\mathrm{BB}}$ component dominated during winter in Ioannina $(77 \%)$ and was considerable in Athens (40\%), and notwithstanding the uncertainties tied in this empirical approach, it seemed to provide reasonable results. Evaluation of the $\mathrm{POC}_{\mathrm{bb}}$ estimates against $\mathrm{BC}_{\mathrm{bb}}$ and $\mathrm{BBOA}$ in Athens resulted in high correlations $\left(R^{2}=0.95\right.$ and 0.84 , respectively), whereas comparisons with an alternative method using different primary OC/EC ratios for fossil-fuel and BB emissions resulted in discrepancies less than $15 \%$. However, more research is required to attain robust findings using this approach, with the use of more specific BB tracers (e.g., levoglucosan) expected to improve the estimates of POC (and SOC) components, especially in atmospheres highly impacted by BB aerosols. 
Supplementary Materials: The following are available online at http://www.mdpi.com/2073-4433/11/2/161/s1: Figure S1: Application of the MRS method for Ioannina and Heraklion. At Ioannina, (OC/EC)pri = 6.10; @46.97\% means that $\sim 53 \%$ of data would have positive SOC, while in Heraklion $89 \%$ of the data have positive SOC values. Lognormal curves are fitted in the OC/EC frequency distributions; Figure S2: TSP, OC, EC concentrations and their ratios during dry and rainy days in Ioannina (a) and Heraklion (b). The percentage changes due to rainfall are also given for day and night samples; Figure S3: Day vs night concentrations of the carbonaceous-aerosol and inorganic species (in TSP) in Ioannina (a) and Heraklion (b); Figure S4: Correlations between OC, EC concentrations and nss- $\mathrm{K}^{+}, \mathrm{C}_{2} \mathrm{O}_{4}{ }^{2-}$ in Ioannina $(\mathrm{a}, \mathrm{b})$ and Heraklion $(\mathrm{c}, \mathrm{d})$; Figure S5: Correlations between the estimated SOC concentrations obtained from the MRS and percentile (5\%, 25\%) methods in Ioannina and Heraklion; Figure S6: Correlation between the SOC estimates from the various SOC estimation methods and the Delta-C values derived from Aethalometer (AE-33) measurements in Athens during December 2016-January 2017; Table S1: Measurement periods and number of samples at each site in the current study. Table S2: Pearson correlation coefficients (r) from the linear regressions of TSP, OC and EC concentrations with meteorological variables in Ioannina; Table S3: Pearson correlation coefficient (r) matrix between carbonaceous aerosols and ionic species in Ioannina. Values in boldface correspond to statistically significant correlations at the 95\% confidence level; Table S4: Same as in Suppl. Table S3, but for Heraklion.

Author Contributions: Conceptualization, D.G.K., G.G., and N.M.; measurements, C.T., M.T., D.P., I.S., E.L., and A.G.; investigation, D.G.K. and C.W.; data curation, C.T., M.T., D.P., and I.S.; writing-original draft preparation, D.G.K.; writing-review and editing, D.G.K., G.G., E.L., and N.M.; visualization, D.G.K., A.G., and C.W.; supervision, N.H., E.G., and N.M.; project administration, E.G. and N.M.; funding acquisition, E.G. and N.M. All authors have read and agreed to the published version of the manuscript.

Funding: This research was funded by the project "PANhellenic infrastructure for Atmospheric Composition and climatE change" (MIS 5021516), which is implemented under the Action "Reinforcement of the Research and Innovation Infrastructure", funded by the Operational Program "Competitiveness, Entrepreneurship and Innovation" (NSRF 2014-2020) and co-financed by Greece and the European Union (European Regional Development Fund).

Acknowledgments: I.S. and E.G. acknowledge the support received by ERA-PLANET (www.era-planet.eu), trans-national project SMURBS (www.smurbs.eu) (grant agreement no. 689443), funded under the EU Horizon 2020 Framework Program.

Conflicts of Interest: The authors declare no conflict of interest.

\section{References}

1. Bond, T.C.; Doherty, S.J.; Fahey, D.W.; Forster, P.M.; Berntsen, T.; De Angelo, B.J. Bounding the role of black carbon in the climate system: A scientific assessment. J. Geophys. Res. 2013, 118, 5380-5552. [CrossRef]

2. Samburova, V.; Connolly, J.; Gyawali, M.; Yatavelli, R.L.N.; Watts, A.C.; Chakrabarty, R.K. Polycyclic aromatic hydrocarbons in biomass-burning emissions and their contribution to light absorption and aerosol toxicity. Sci. Total Environ. 2016, 568, 391-401. [CrossRef] [PubMed]

3. Contini, D.; Vecchi, R.; Viana, M. Carbonaceous Aerosols in the Atmosphere. Atmosphere 2018, 9, 181. [CrossRef]

4. Yan, J.; Wang, X.; Gong, P.; Wang, C.; Cong, Z. Review of brown carbon aerosols: Recent progress and perspectives. Sci. Total Environ. 2018, 634, 1475-1485. [CrossRef] [PubMed]

5. Cappa, C.D.; Onasch, T.B.; Massoli, P.; Worsnop, D.R.; Bates, T.S.; Cross, E.S. Radiative absorption enhancements due to the mixing state of atmospheric black carbon. Science 2012, 337, 1078-1081. [CrossRef] [PubMed]

6. Samset, B.H.G.; Myhre, A.; Herber, Y.; Kondo, S.-M.; Li, N.; Moteki, M.; Koike, N. Modelled black carbon radiative forcing and atmospheric lifetime in AeroCom Phase II constrained by aircraft observations. Atmos. Chem. Phys. 2014, 14, 12465-12477. [CrossRef]

7. Bisht, D.S.; Dumka, U.C.; Kaskaoutis, D.G.; Pipal, A.S.; Srivastava, A.K.; Soni, V.K.; Attri, S.D.; Sateesh, M.; Tiwari, S. Carbonaceous aerosols and pollutants over Delhi urban environment: Temporal evolution, source apportionment and radiative forcing. Sci. Total Environ. 2015, 521-522, 431-445. [CrossRef]

8. Hallquist, M.; Wenger, J.C.; Baltensperger, U.; Rudich, Y. The formation, properties and impact of secondary organic aerosol: Current and emerging issues. Atmos. Chem. Phys. 2009, 9, 5155-5236. [CrossRef]

9. Mohr, C.; Lopez-Hilfiker, F.D.; Zotter, P.; Prévôt, A.S.; Xu, L.; Ng, N.L.; Herndon, S.C.; Williams, L.R.; Franklin, J.P.; Zahniser, M.S. Contribution of nitrated phenols to wood burning brown carbon light absorption in Detling, United Kingdom during winter time. Environ. Sci. Technol. 2013, 47, 6316-6324. [CrossRef] 
10. Nozière, B.; Kalberer, M.; Claeys, M.; Allan, J. The Molecular Identification of Organic Compounds in the Atmosphere: State of the Art and Challenges. Chem. Rev. 2015, 115, 3919-3983. [CrossRef]

11. Satish, R.; Rastogi, N. On the use of brown carbon spectra as a tool to understand their broader composition and characteristics: A case study from crop residue burning samples. ACS Omega 2019, 4, 1847-1853. [CrossRef] [PubMed]

12. Saleh, R.; Marks, M.; Heo, J.; Adams, P.J.; Donahue, N.M.; Robinson, A.L. Contribution of brown carbon and lensing to the direct radiative effect of carbonaceous aerosols from biomass and biofuel burning emissions. J. Geophys. Res. 2015, 120, 10.285-10.296.

13. Shamjad, P.M.; Tripathi, S.N.; Pathak, R.; Hallquist, M.; Arola, A.; Bergin, M.H. Contribution of Brown Carbon to Direct Radiative Forcing over the Indo-Gangetic Plain. Environ. Sci. Technol. 2015, 49, 10474-10481. [CrossRef] [PubMed]

14. Bikkina, S.; Sarin, M.M. Brown Carbon in the continental outflow to the North Indian Ocean. Environ. Sci. Processes Impacts 2019, 21, 970-987. [CrossRef] [PubMed]

15. Sarkar, C.; Sinha, V.; Sinha, B.; Pandey, A.K.; Rupakheti, M.; Lawrence, M.G. Source apportionment of NMVOCs in the Kathmandu Valley during the SusKat-ABC international field campaign using positive matrix factorization. Atmos. Chem. Phys. 2017, 17, 8129-8156. [CrossRef]

16. Pani, S.K.; Lin, N.-H.; Chantara, S.; Wang, S.-H.; Khamkaew, C.; Prapamontol, T.; Janjai, S. Radiative response of biomass-burning aerosols over an urban atmosphere in northern peninsular Southeast Asia. Sci. Total Environ. 2018, 633, 892-911. [CrossRef]

17. Cheng, Y.; Engling, G.; He, K.-B.; Duan, F.-K.; Ma, Y.-L.; Du, Z.-Y.; Liu, J.-M.; Zheng, M.; Weber, R.J. Biomass burning contribution to Beijing aerosol. Atmos. Chem. Phys. 2013, 13, 7765-7781. [CrossRef]

18. Bosch, C.; Andersson, A.; Kirillova, E.N.; Budhavant, K.; Tiwari, S.; Praveen, P.S.; Russell, L.M.; Beres, N.D.; Ramanathan, V.; Gustafsson, Ö. Source diagnostic dual isotope composition and optical properties of water-soluble organic carbon and elemental carbon in the South Asian outflow intercepted over the Indian Ocean. J. Geophys. Res. 2014, 119. [CrossRef]

19. Saffari, A.; Daher, N.; Samara, C.; Voutsa, D.; Kouras, A.; Manoli, E.; Karagkiozidou, O.; Vlachokostas, C.; Moussiopoulos, N.; Shafer, M.M.; et al. Increased biomass burning due to the economic crisis in Greece and its adverse impact on wintertime air quality in Thessaloniki. Environ. Sci. Technol. 2013, 47, 13313-13320. [CrossRef]

20. Paraskevopoulou, D.; Liakakou, E.; Gerasopoulos, E.; Theodosi, C.; Mihalopoulos, N. Long-term characterization of organic and elemental carbon in the PM2.5 fraction: The case of Athens, Greece. Atmos. Chem. Phys. 2014, 14, 13313-13325. [CrossRef]

21. Paraskevopoulou, D.; Liakakou, E.; Gerasopoulos, E.; Mihalopoulos, N. Sources of atmospheric aerosol from long-term measurements (5years) of chemical composition in Athens, Greece. Sci. Total Environ. 2015, 527-528, 165-178. [CrossRef] [PubMed]

22. Diapouli, E.; Manousakas, M.; Vratolis, S.; Vasilatou, V.; Maggos, T.; Saraga, D.; Grigoratos, T.; Argyropoulos, G.; Voutsa, D.; Samara, C. Evolution of air pollution source contributions over one decade, derived by PM10 and PM2.5 source apportionment in two metropolitan urban areas in Greece. Atmos. Environ. 2017, 164, 416-430. [CrossRef]

23. Gratsea, M.; Liakakou, E.; Mihalopoulos, N.; Adamopoulos, A.; Tsilibari, E.; Gerasopoulos, E. The combined effect of reduced fossil fuel consumption and increasing biomass combustion on Athens' air quality, as inferred from long term CO measurements. Sci. Total Environ. 2017, 592, 115-123. [CrossRef]

24. Theodosi, C.; Tsagkaraki, M.; Zarmpas, P.; Liakakou, E.; Grivas, G.; Paraskevopoulou, D.; Lianou, M.; Gerasopoulos, E.; Mihalopoulos, N. Multiyear chemical composition of the fine aerosol fraction in Athens, Greece, with emphasis on winter-time residential heating. Atmos. Chem. Phys. 2018, 18, 14371-14391. [CrossRef]

25. Fourtziou, L.; Liakakou, E.; Stavroulas, I.; Theodosi, C.; Zarmpas, P.; Psiloglou, B.; Sciare, J.; Maggos, T.; Bairachtari, K.; Bougiatioti, A.; et al. Multi-tracer approach to characterize domestic wood burning in Athens (Greece) during wintertime. Atmos. Environ. 2017, 148, 89-101. [CrossRef]

26. Panopoulou, A.; Liakakou, E.; Gros, V.; Sauvage, S.; Locoge, N.; Bonsang, B.; Psiloglou, B.E.; Gerasopoulos, E.; Mihalopoulos, N. Non Methane Hydrocarbons variability in Athens during wintertime: The role of traffic and heating. Atmos. Chem. Phys. 2018, 18, 16139-16154. [CrossRef] 
27. Florou, K.; Papanastasiou, D.K.; Pikridas, M.; Kaltsonoudis, C.; Louvaris, E.; Gkatzelis, G.I.; Patoulias, D.; Mihalopoulos, N.; Pandis, S.N. The contribution of wood burning and other pollution sources to wintertime organic aerosol levels in two Greek cities. Atmos. Chem. Phys. 2017, 17, 3145-3163. [CrossRef]

28. Pateraki, S.; Assimakopoulos, V.D.; Bougiatioti, A.; Kouvarakis, G.; Mihalopoulos, N.; Vasilakos, C. Carbonaceous and ionic compositional patterns of fine particles over an urban Mediterranean area. Sci. Total Environ. 2012, 424, 251-263. [CrossRef]

29. Mantas, E.; Remoundaki, E.; Halari, I.; Kassomenos, P.; Theodosi, C.; Hatzikioseyian, A.; Mihalopoulos, N. Mass closure and source apportionment of PM2.5 by Positive Matrix Factorization analysis in urban Mediterranean environment. Atmos. Environ. 2014, 94, 154-163. [CrossRef]

30. Diapouli, E.; Kalogridis, A.C.; Markantonaki, C.; Vratolis, S.; Fetfatzis, P.; Colombi, C.; Eleftheriadis, K. Annual variability of Black Carbon concentrations originating from biomass and fossil fuel combustion for the suburban aerosol in Athens, Greece. Atmosphere 2017, 8, 234. [CrossRef]

31. Grivas, G.; Cheristanidis, S.; Chaloulakou, A.; Koutrakis, P.; Mihalopoulos, N. Elemental composition and source apportionment of fine and coarse particles at traffic and urban background locations in Athens, Greece. Aer. Air Qual. Res. 2018, 18, 1642-1659. [CrossRef]

32. Kalogridis, A.C.; Vratolis, S.; Liakakou, E.; Gerasopoulos, E.; Mihalopoulos, N.; Eleftheriadis, K. Assessment of wood burning versus fossil fuel contribution to wintertime black carbon and carbon monoxide concentrations in Athens, Greece. Atmos. Chem. Phys. 2018, 18, 10219-10236. [CrossRef]

33. Stavroulas, I.; Bougiatioti, A.; Paraskevopoulou, D.; Grivas, G.; Liakakou, E.; Gerasopoulos, E.; Mihalopoulos, N. Sources and processes that control the submicron organic aerosol in an urban Mediterranean environment (Athens) using high temporal resolution chemical composition measurements. Atmos. Chem. Phys. 2019, 19, 901-919. [CrossRef]

34. Liakakou, E.; Stavroulas, I.; Kaskaoutis, D.G.; Grivas, G.; Paraskevopoulou, D.; Dumka, U.C.; Tsagkaraki, M.; Bougiatioti, A.; Oikonomou, K.; Sciare, J.; et al. Long-term variability, source apportionment and spectral properties of black carbon at an urban background site in Athens, Greece. Atmos. Environ. 2020, 222, 117137. [CrossRef]

35. Liakakou, E.; Kaskaoutis, D.G.; Grivas, G.; Stavroulas, I.; Tsagkaraki, M.; Paraskevopoulou, D.; Bougiatioti, A.; Dumka, U.C.; Gerasopoulos, E.; Mihalopoulos, N. Long-term brown carbon spectral characteristics in a Mediterranean city (Athens). Sci. Total Environ. 2020, 708, 135019. [CrossRef]

36. Grivas, G.; Cheristanidis, S.; Chaloulakou, A. Elemental and organic carbon in the urban environment of Athens. Seasonal and diurnal variations and estimates of secondary organic carbon. Sci. Total Environ. 2012, 414, 535-545. [CrossRef]

37. Samara, C.; Voutsa, D.; Kouras, A.; Eleftheriadis, K.; Maggos, T.; Saraga, D.; Petrakakis, M. Organic and elemental carbon associated to PM10 and PM2.5 at urban sites of northern Greece. Environ. Sci. Pollut. Res. 2014, 21, 1769-1785. [CrossRef] [PubMed]

38. Bougiatioti, A.; Zarmpas, P.; Koulouri, E.; Antoniou, M.; Theodosi, C.; Kouvarakis, G.; Saarikoski, S.; Mäkelä, T.; Hillamo, R.; Mihalopoulos, N. Organic, elemental and water-soluble organic carbon in size segregated aerosols, in the marine boundary layer of the eastern Mediterranean. Atmos. Environ. 2013, 64, 251-262. [CrossRef]

39. Paraskevopoulou, D.; Bougatioti, A.; Stavroulas, I.; Fang, T.; Lianou, M.; Liakakou, E.; Gerasopoulos, E.; Weber, R.; Nenes, A.; Mihalopoulos, N. Yearlong variability of oxidative potential of particulate matter in an urban Mediterranean environment. Atmos. Environ. 2019, 206, 183-196. [CrossRef]

40. Turpin, B.J.; Huntzicker, J.J. Identification of secondary organic aerosol episodes and quantification of primary and secondary organic aerosol concentrations during SCAQS. Atmos Environ. 1995, 23, 3527-3544. [CrossRef]

41. Wu, C.; Yu, J.Z. Determination of primary combustion source organic carbon-to-elemental carbon (OC/EC) ratio using ambient OC and EC measurements: Secondary OC-EC correlation minimization method. Atmos. Chem. Phys. 2016, 16, 5453-5465. [CrossRef]

42. Wu, C.; Wu, D.; Yu, J.Z. Estimation and uncertainty analysis of secondary organic carbon using 1 year of hourly organic and elemental carbon data. J. Geophys. Res. 2019, 124, 2774-2795. [CrossRef]

43. Houssos, E.E.; Lolis, C.J.; Gkikas, A.; Hatzianastassiou, N.; Bartzokas, A. On the Atmospheric Circulation Characteristics Associated with Fog in Ioannina, North-Western Greece. Int. J. Climatol. 2012, 32, 1847-1862. [CrossRef] 
44. Sindosi, O.A.; Markozannes, G.; Rizos, E.; Ntzani, E. Effects of economic crisis on air quality in Ioannina, Greece. J. Environ. Sci. Health Part A 2019, 54, 768-781. [CrossRef]

45. Solomos, S.; Kalivitis, N.; Mihalopoulos, N.; Amiridis, V.; Kouvarakis, G.; Gkikas, A.; Binietoglou, I.; Tsekeri, A.; Kazadzis, S.; Kottas, M.; et al. From Tropospheric Folding to Khamsin and Foehn Winds: How Atmospheric Dynamics Advanced a Record-Breaking Dust Episode in Crete. Atmosphere 2018, 9, 240. [CrossRef]

46. Grivas, G.; Stavroulas, I.; Liakakou, E.; Kaskaoutis, D.G.; Bougiatioti, A.; Paraskevopoulou, D.; Gerasopoulos, E.; Mihalopoulos, N. Measuring the spatial variability of Black Carbon in Athens during wintertime. Air Qual. Atmos. Health 2019. [CrossRef]

47. Cavalli, F.; Viana, M.; Yttri, K.E.; Genberg, J.; Putaud, J.P. Toward a standardised thermal-optical protocol for measuring atmospheric organic and elemental carbon: The EUSAAR protocol. Atmos. Meas. Technol. 2010, 3, 79-89. [CrossRef]

48. Karanasiou, A.; Diapouli, E.; Cavalli, F.; Eleftheriadis, K.; Viana, M.; Alastuey, A.; Querol, X.; Reche, C. On the quantification of atmospheric carbonate carbon by thermal/optical analysis protocols. Atmos. Meas. Tech. 2011, 4, 2409-2419. [CrossRef]

49. Pio, C.; Cerqueira, M.; Harrison, R.M.; Nunes, T.; Mirante, F.; Alves, C.; Oliveira, C.; de la Campa, A.S.; Artínano, B.; Matos, M. OC/EC ratio observations in Europe: Re-thinking the approach for apportionment between primary and secondary organic carbon. Atmos. Environ. 2011, 45, 6121-6132. [CrossRef]

50. Ram, K.; Sarin, M.M. Day-night variability of EC, OC, WSOC and inorganic ions in urban environment of Indo-Gangetic Plain: Implications to secondary aerosol formation. Atmos. Environ. 2011, 45, 460-468. [CrossRef]

51. Dumka, U.C.; Tiwari, S.; Kaskaoutis, D.G.; Hopke, P.K.; Singh, J.; Srivastava, A.K.; Bisht, D.S.; Attri, S.D.; Tyagi, S.; Misra, A.; et al. Assessment of PM2.5 chemical compositions in Delhi: Primary vs secondary emissions and contribution to light extinction coefficient and visibility degradation. J. Atmos. Chem. 2017, 74, 423-450. [CrossRef]

52. Castro, L.M.; Pio, C.A.; Harrison, R.M.; Smith, D.J.T. Carbonaceous aerosol in urban and rural European atmospheres: Estimation of secondary organic carbon concentrations. Atmos Environ. 1999, 33, 2771-2781. [CrossRef]

53. Day, M.C.; Zhang, M.; Pandis, S.N. Evaluation of the ability of the EC tracer method to estimate secondary organic carbon. Atmos. Environ. 2015, 112, 317-325. [CrossRef]

54. Millet, D.B.; Donahue, N.M.; Pandis, S.N.; Polidori, A.; Stanier, C.O.; Turpin, B.J.; Goldstein, A.H. Atmospheric volatile organic compound measurements during the Pittsburgh Air Quality Study: Results, interpretation, and quantification of primary and secondary contributions. J. Geophys. Res. 2005, 110, D07S07. [CrossRef]

55. Caserini, S.; Galante, S.; Ozgen, S.; Cucco, S.; Gregorio, K.; Moretti, M. A methodology for elemental and organic carbon emission inventory and results for Lombardy region, Italy. Sci. Total Environ. 2013, 450, 22-30. [CrossRef]

56. Terzi, E.; Argyropoulos, G.; Bougatioti, A.; Mihalopoulos, N.; Nikolaou, K.; Samara, C. Chemical composition and mass closure of ambient PM10 at urban sites. Atmos. Environ. 2010, 44, 2231-2239. [CrossRef]

57. Kong, S.; Han, B.; Bai, Z.; Chen, L.; Shi, J.; Xu, Z. Receptor modeling of PM2.5, PM10 and TSP in different seasons and long-range transport analysis at a coastal site of Tianjin, China. Sci. Total Environ. 2010, 408, 4681-4694. [CrossRef]

58. Cao, J.-J.; Zhu, C.-S.; Tie, X.-X.; Geng, F.-H.; Xu, H.-M.; Ho, S.S.H.; Wang, G.-H.; Han, Y.-M.; Ho, K.-F. Characteristics and sources of carbonaceous aerosols from Shanghai, China. Atmos. Chem. Phys. 2013, 13, 803-817. [CrossRef]

59. Satsangi, A.; Pachauri, T.; Singla, V.; Lakhani, A.; Kumari, K.M. Organic and elemental carbon aerosols at a suburban site. Atmos. Res. 2012, 113, 13-21. [CrossRef]

60. Gupta, A.K.; Karar, K.; Srivastava, A. Chemical mass balance source apportionment of PM10 and TSP in residential and industrial sites of an urban region of Kolkata, India. J. Hazard. Mater. 2007, 142, 279-287. [CrossRef]

61. Chalikias, M.S.; Kyriakopoulos, G.; Kolovos, K.G. Environmental sustainability and financial feasibility evaluation of woodfuel biomass used for a potential replacement of conventional space heating sources. Part I: A Greek case study. Oper. Res. 2009, 10, 43-56. [CrossRef] 
62. Alfarra, M.R.; Prevot, A.S.H.; Szidat, S.; Sandradewi, J.; Weimer, S.; Lanz, V.A.; Schreiber, D.; Mohr, M.; Baltensperger, U. Identification of the mass spectral signature of organic aerosols from wood burning emissions. Environ. Sci. Technol. 2007, 41, 5770-5777. [CrossRef] [PubMed]

63. Sandradewi, J.; Prevot, A.S.H.; Szidat, S.; Perron, N.; Alfarra, M.R.; Lanz, V.A.; Weingartner, E.; Baltensperger, U. Using Aerosol Light Absorption Measurements for the Quantitative Determination of Wood Burning and Traffic Emission Contributions to Particulate Matter. Environ. Sci. Technol. 2008, 42, 3316-3323. [CrossRef] [PubMed]

64. Martinsson, J.; Abdul Azeem, H.; Sporre, M.K.; Bergström, R.; Ahlberg, E.; Öström, E.; Kristensson, A.; Swietlicki, E.; Eriksson Stenström, K. Carbonaceous aerosol source apportionment using the Aethalometer model - evaluation by radiocarbon and levoglucosan analysis at a rural background site in southern Sweden. Atmos. Chem. Phys. 2017, 17, 4265-4281. [CrossRef]

65. Zotter, P.; Herich, H.; Gysel, M.; El-Haddad, I.; Zhang, Y.; Močnik, G.; Hüglin, C.; Baltensperger, U.; Szidat, S.; Prévôt, A.S.H. Evaluation of the absorption Ångström exponents for traffic and wood burning in the Aethalometer-based source apportionment using radiocarbon measurements of ambient aerosol. Atmos. Chem. Phys. 2017, 17, 4229-4249. [CrossRef]

66. Salameh, T.; Sauvage, S.; Afif, C.; Borbon, A.; Léonardis, T.; Brioude, J.; Waked, A.; Locoge, N. Exploring the seasonal NMHC distribution in an urban area of the Middle East during ECOCEM campaigns: Very high loadings dominated by local emissions and dynamics. Environ. Chem. 2014, 12, 316-328. [CrossRef]

67. Panda, S.; Sharma, S.K.; Mhapatra, P.S.; Panda, U.; Rath, S.; Mhapatra, M.; Mandal, T.K.; Das, T. Organic and elemental carbon variation in PM2.5 over megacity Delhi and Bhubaneswar, a semi-urban coastal site in India. Nat. Hazards 2016, 80, 1709-1728. [CrossRef]

68. Ram, K.; Sarin, M.M. Atmospheric carbonaceous aerosols from Indo-Gangetic Plain and Central Himalaya: Impact of anthropogenic sources. J. Environ. Manag. 2015, 148, 153-163. [CrossRef]

69. Costabile, F.; Alas, H.; Aufderheide, M.; Avino, P.; Amato, F.; Constantini, S.; Argentini, S.; Barnaba, F.; Berico, M.; Bernardoni, V. First Results of the "Carbonaceous Aerosol in Rome and Environs (CARE)" Experiment: Beyond Current Standards for PM10. Atmosphere 2017, 8, 249. [CrossRef]

70. Ram, K.; Sarin, M.M.; Tripathi, S.N. Temporal trends in atmospheric PM2.5, PM10, elemental carbon, organic carbon, water-soluble organic carbon, and optical properties: Impact of biomass burning emissions in the Indo-Gangetic Plain. Environ. Sci. Technol. 2012, 46, 686-695. [CrossRef]

71. Vicente, E.D.; Alves, C.A. An overview of particulate emissions from residential biomass combustion. Atmos. Res. 2018, 199, 159-185. [CrossRef]

72. Watson, J.G.; Chow, J.C.; Houck, J.E. PM PM.5 $_{\text {che }}$ chical source profiles for vehicle exhaust, vegetative burning, geological material, and coal burning in Northwestern Colorado during 1995. Chemosphere 2001, 43, 1141-1151. [CrossRef]

73. Ram, K.; Sarin, M.M.; Hegde, P. Atmospheric abundances of primary and secondary carbonaceous species at two high-altitude sites in India: Sources and temporal variability. Atmos. Environ. 2008, 42, 6785-6796. [CrossRef]

74. Jedynska, A.; Hoek, G.; Eeftens, M.; Cyrys, J.; Keuken, M. Spatial variations of PAH, hopanes/steranes and EC/OC concentrations within and between European study areas. Atmos. Environ. 2014, 87, 239-248. [CrossRef]

75. Dumka, U.C.; Kaskaoutis, D.G.; Devara, P.C.S.; Kumar, R.; Kumar, S.; Tiwari, S.; Gerasopoulos, E.; Mihalopoulos, N. Year-long variability of the fossil fuel and wood burning black carbon components at a rural site in southern Delhi outskirts. Atmos. Res. 2019, 216, 11-25. [CrossRef]

76. Katsanos, D.; Bougiatioti, A.; Liakakou, E.; Kaskaoutis, D.G.; Stavroulas, I.; Paraskevopoulou, D.; Lianou, M.; Psiloglou, B.E.; Gerasopoulos, E.; Pilinis, C.; et al. Optical Properties of Near-surface Urban Aerosols and their Chemical Tracing in a Mediterranean City (Athens). Aeros. Air Qual. Res. 2019, 19, 49-70. [CrossRef]

77. Athanasopoulou, E.; Speyer, O.; Brunner, D.; Vogel, H.; Vogel, B.; Mihalopoulos, N.; Gerasopoulos, E. Changes in the domestic heating fuel in Greece: Effects on atmospheric chemistry and radiation. Atmos. Chem. Phys. 2017, 17, 10597-10618. [CrossRef]

78. Rastogi, N.; Singh, A.; Sarin, M.M.; Singh, D. Temporal variability of primary and secondary aerosols over northern India: Impact of biomass burning emissions. Atmos. Environ. 2016, 125, 396-403. [CrossRef]

79. Singh, A.; Rastogi, N. Quantification of Organic Carbon from Biomass Versus Non-Biomass Burning Emissions to Fine Aerosol. Proc. Indian Nat. Sci. Acad. 2019, 85, 629-636. 
80. Myriokefalitakis, S.; Tsigaridis, K.; Mihalopoulos, N.; Sciare, J.; Nenes, A.; Kawamura, K.; Segers, A.; Kanakidou, M. In-cloud oxalate formation in the global troposphere: A 3-D modeling study. Atmos. Chem. Phys. 2011, 11, 5761-5782. [CrossRef]

81. Gerasopoulos, E.; Kouvarakis, G.; Babasakalis, P.; Vrekoussis, M.; Putaud, J.-P.; Mihalopoulos, N. Origin and variability of particulate matter (PM10) mass concentrations over the Eastern Mediterranean. Atmos. Environ. 2006, 40, 4679-4690. [CrossRef]

82. Andreae, M.O.; Merlet, P. Emission of Trace Gases and Aerosols from Biomass Burning. Glob. Biogeochem. Cycles 2001, 15, 955-966. [CrossRef]

83. Bougiatioti, A.; Nenes, A.; Fountoukis, C.; Kalivitis, N.; Pandis, S.N.; Mihalopoulos, N. Size-resolved CCN distributions and activation kinetics of aged continental and marine aerosol. Atmos. Chem. Phys. 2011, 11, 8791-8808. [CrossRef]

84. Bougiatioti, A.; Nikolaou, P.; Stavroulas, I.; Kouvarakis, G.; Weber, R.; Nenes, A.; Kanakidou, M.; Mihalopoulos, N. Particle water and $\mathrm{pH}$ in the eastern Mediterranean: Source variability and implications for nutrient availability. Atmos. Chem. Phys. 2016, 16, 4579-4591. [CrossRef]

85. Qin, M.Y.; Tan, B.H.; Li, Y.J.; Schurman, M.I.; Li, F.; Canonaco, F.; Prévôt, A.S.H.; Chan, C.K. Impacts of traffic emissions on atmospheric particulate nitrate and organics at a downwind site on the periphery of Guangzhou, China. Atmos. Chem. Phys. 2017, 17, 10245-10258. [CrossRef]

86. Calvo, A.I.; Pont, V.; Liousse, C.; Dupre, B.; Mariscal, A.; Zouiten, C. Chemical composition of urban aerosols in Toulouse, France during CAPITOUL experiment. Meteorol. Atmos. Phys. 2008, 102, 307-323. [CrossRef]

87. Galindo, N.; Yubero, E.; Clemente, A.; Nicolás, J.F.; Navarro-Selma, B.; Crespo, J. Insights into the origin and evolution of carbonaceous aerosols in a mediterranean urban environment. Chemosphere 2019, 235, 636-642. [CrossRef]

88. Merico, E.; Cesari, D.; Dinoi, A.; Gambaro, A.; Barbaro, E.; Guascito, M.R.; Giannossa, L.C.; Mangone, A.; Contini, D. Inter-comparison of carbon content in PM10 and PM2.5 measured with two thermo-optical protocols on samples collected in a Mediterranean site. Environ. Sci. Poll. Res. 2019, 26, 29334-29350. [CrossRef]

89. Wagener, S.; Langner, M.; Hansen, U.; Moriske, H.-J.; Endlicher, W.R. Assessing the Influence of Seasonal and Spatial Variations on the Estimation of Secondary Organic Carbon in Urban Particulate Matter by Applying the EC-Tracer Method. Atmosphere 2014, 5, 252-272. [CrossRef]

90. Shivani; Gadi, R.; Sharma, S.K.; Mandal, T.K. Seasonal variation, source apportionment and source attributed health risk of fine carbonaceous aerosols over National Capital Region, India. Chemosphere 2019. [CrossRef]

91. Pachauri, T.; Satsangi, A.; Singla, V. Characteristics and sources 614 of carbonaceous 615 aerosols in PM2. 5 during wintertime in Agra, India. Aeros. Air Qual. Res. 2013, 13, 977-991. [CrossRef]

92. Liu, T.; Wang, Z.; Wang, X.; Chan, C.K. Primary and secondary organic aerosol from heated cooking oil emissions. Atmos. Chem. Phys. 2018, 18, 11363-11374. [CrossRef]

93. Zhang, Y.; Ren, H.; Sun, Y.; Cao, F.; Chang, Y.; Liu, S. High Contribution of Nonfossil Sources to Submicrometer Organic Aerosols in Beijing, China. Environ. Sci. Technol. 2017, 51, 7842-7852. [CrossRef] [PubMed]

94. Ensberg, J.J.; Hayes, P.L.; Jimenez, J.L.; Gilman, J.B.; Kuster, W.C.; de Gouw, J.A. Emission factor ratios, SOA mass yields, and the impact of vehicular emissions on SOA formation. Atmos. Chem. Phys. 2014, 14, 2383-2397. [CrossRef]

95. Sciare, J.; D'Argouges, O.; Sarda-Esteve, R.; Gaimoz, C.; Dolgorouky, C.; Bonnaire, N.; Favez, O.; Bonsang, B.; Gros, V. Large contribution of water-insoluble secondary organic aerosols in the region of Paris (France) during wintertime. J. Geophys. Res. 2011, 116, D22203. [CrossRef]

96. Singh, A.; Satish, R.V.; Rastogi, N. Characteristics and sources of fine organic aerosol over a big semi-arid urban city of western India using HR-ToF-AMS. Atmos. Environ. 2019, 208, 103-112. [CrossRef]

97. Wang, Y.; Hopke, P.K.; Rattigan, O.V.; Xia, X.; Chalupa, D.C.; Utell, M.J. Characterization of residential wood combustion particles using the two-wavelength aethalometer. Environ. Sci. Technol. 2011, 45, 7387-7393. [CrossRef]

98. Hildebrandt, L.; Kostenidou, E.; Lanz, V.A.; Prevot, A.S.H.; Baltensperger, U.; Mihalopoulos, N.; Laaksonen, A.; Donahue, N.M.; Pandis, S.N. Sources and atmospheric processing of organic aerosol in the Mediterranean: Insights from aerosol mass spectrometer factor analysis. Atmos. Chem. Phys. 2011, 11, 12499-12515. [CrossRef] 
99. Rinaldi, M.; Gilardoni, S.; Paglione, M.; Sandrini, S.; Fuzzi, S.; Massoli, P.; Bonasoni, P.; Cristofanelli, P.; Marinoni, A.; Poluzzi, V.; et al. Organic aerosol evolution and transport observed at Mt. Cimone $(2165 \mathrm{~m}$ a.s.1.), Italy, during the PEGASOS campaign. Atmos. Chem. Phys. 2015, 15, 11327-11340. [CrossRef]

100. Mohr, C.; Huffman, J.A.; Cubison, M.J.; Aiken, A.C.; Docherty, K.S.; Kimmel, J.R. Characterization of primary organic aerosol emissions from meat cooking, trash burning, and motor vehicles with high-resolution aerosol mass spectrometry and comparison with ambient and chamber observations. Environ. Sci. Technol. 2009, 43, 2443-2449. [CrossRef]

101. Daellenbach, K.R.; Stefenelli, G.; Bozzetti, C.; Vlachou, A.; Fermo, P.; Gonzalez, R.; Piazzalunga, A.; Colombi, C.; Canonaco, F.; Hueglin, C.; et al. Long-term chemical analysis and organic aerosol source apportionment at nine sites in central Europe: Source identification and uncertainty assessment. Atmos. Chem. Phys. 2017, 17, 13265-13282. [CrossRef]

102. Szidat, S.; Jenk, T.M.; Synal, H.A.; Kalberer, M.; Wacker, L.; Hajdas, I.; Kasper-Giebl, A.; Baltensperger, U. Contribution of fossil fuel, biomass-burning and biogenic emissions to carbonaceous aerosols in Zurich as traced by 14C. J. Geophys. Res. 2006, 111, D07206. [CrossRef]

103. Zhang, Y.-L.; Huang, R.-J.; El Haddad, I.; Ho, K.-F.; Cao, J.-J.; Han, Y. Fossil vs. non-fossil sources of fine carbonaceous aerosols in four Chinese cities during the extreme winter haze episode of 2013. Atmos. Chem. Phys. 2015, 15, 1299-1312. [CrossRef]

104. Srivastava, D.; Favez, O.; Perraudin, E.; Villenave, E.; Albinet, A. Comparison of measurement-based methodologies to apportion secondary organic carbon (SOC) in PM2.5: A review of recent studies. Atmosphere 2018, 9, 452. [CrossRef]

105. Titos, G.; del Águila, A.; Cazorla, A.; Lyamani, H.; Casquero-Vera, J.A.; Colombi, C.; Cuccia, E.; Gianelle, V.; Močnik, G.; Alastuey, A.; et al. Spatial and temporal variability of carbonaceous aerosols: Assessing the impact of biomass burning in the urban environment. Sci. Total Environ. 2017, 578, 613-625. [CrossRef]

106. Jedynska, A.; Hoek, G.; Wang, M.; Eeftens, M.; Cyrys, J.; Beelen, R. Spatial variations of levoglucosan in four European study areas. Sci. Total Environ. 2015, 505, 1072-1081. [CrossRef]

107. Wan, X.; Kang, S.; Li, Q.; Rupakheti, D.; Zhang, Q.; Guo, J.; Chen, P.; Tripathee, L.; Rupakheti, M.; Panday, A.K.; et al. Organic molecular tracers in the atmospheric aerosols from Lumbini, Nepal, in the northern Indo-Gangetic Plain: Influence of biomass burning. Atmos. Chem. Phys. 2017, 17, 8867-8885. [CrossRef]

108. Srinivas, B.; Andersson, A.; Sarin, M.M.; Sheesley, R.J.; Kirillova, E.; Rengarajan, R.; Sudheer, A.K.; Ram, K.; Gustafsson, Ö. Dual carbon isotope characterization of total organic carbon in wintertime carbonaceous aerosols from northern India. J. Geophys. Res. 2016, 121, 4797-4809. [CrossRef]

109. Zhang, Q.; Sarkar, S.; Wang, X.; Zhang, J.; Mao, J.; Yang, L.; Shi, Y.; Jia, S. Evaluation of factors influencing secondary organic carbon (SOC) estimation by CO and EC tracer methods. Sci. Total Environ. 2019, 686, 915-930. [CrossRef]

110. Chen, Y.; Xie, S.; Luo, B.; Zhai, C. Characteristics and origins of carbonaceous aerosol in the Sichuan Basin, China. Atmos. Environ. 2014, 94, 215-223. [CrossRef]

(C) 2020 by the authors. Licensee MDPI, Basel, Switzerland. This article is an open access article distributed under the terms and conditions of the Creative Commons Attribution (CC BY) license (http://creativecommons.org/licenses/by/4.0/). 